\title{
Biodiesel: An Overview
}

\author{
Angelo C. Pinto ${ }^{a}$, Lilian L. N. Guarieiro ${ }^{a}$, Michelle J. C. Rezende ${ }^{a}$, Núbia M. Ribeiro ${ }^{a}$, Ednildo A. \\ Torres $^{b}$, Wilson A. Lopes ${ }^{c}$, Pedro A. de P. Pereira ${ }^{c}$ and Jailson B. de Andrade ${ }^{*, c}$ \\ ${ }^{a}$ Instituto de Química, Universidade Federal do Rio de Janeiro, \\ Centro de Tecnologia, Bloco A, Sala 621, Ilha do Fundão, 21949-900 Rio de Janeiro - RJ, Brazil \\ ${ }^{b}$ Departamento de Engenharia Química, Escola Politécnica, Universidade Federal da Bahia, \\ Rua Aristides Novis, 2, Federação, 40210-630 Salvador - BA, Brazil \\ ${ }^{c}$ Instituto de Química, Universidade Federal da Bahia, Campus de Ondina, 40170-290 Salvador - BA, Brazil
}

\begin{abstract}
A importância da produção de biodiesel, nos últimos cinco anos, é apresentada a partir de artigos científicos publicados e patentes depositadas. Foi realizada uma análise crítica sobre as fontes oleaginosas mais utilizadas como matéria-prima para produção de biodiesel, os catalisadores e os métodos de acompanhamento da reação de transesterificação. Também foram avaliados estudos comparativos entre emissões de diesel fossil e misturas, em várias proporções, com biodiesel. Finalmente, foram indicados desafios enfocando aspectos tecnológicos, agronômicos e de infraestrutura para produção de biodiesel.
\end{abstract}

The importance of biodiesel production was analyzed based on scientific articles and patents. A critical analysis was presented on the most used oil sources, the catalysts and the methods to verify the transesterification yields. Also analyzed were the comparative studies on emissions from pure fossil diesel and mixtures with biodiesel in variable proportions. Finally some challenges and considerations focused on technological, agronomic and infrastructure aspects of biodiesel production were indicated.

Keywords: biodiesel, emissions, transesterification, vegetable oils

\section{Introduction}

The predicted shortage of fossil fuel encouraged the search for substitutes for petroleum derivatives. This search resulted in an alternative fuel called "biodiesel". The concept of biodiesel is still under discussion. Some definitions consider biodiesel as any mixture of vegetable oil and fossil diesel, while others take into account only mixtures of alkyl esters of vegetable oils or animal fats and diesel. The definition adopted by the Brazilian Biodiesel Programme is: "a fuel obtained from mixtures, in different proportions, of fossil diesel and alkyl esters of vegetable oils or animal fats". Technically speaking, biodiesel is the alkyl ester of fatty acids, made by the transesterification of oils or fats, from plants or animals, with short chain alcohols such as methanol and ethanol. Glycerine is, consequently, a by-product from biodiesel production.

* e-mail: jailsong@ufba.br
There are several choices for vegetable oil sources. In Brazil, soybean oil is a source that is already scaled up for biodiesel production. Nevertheless, other sources, such as sunflower, peanut, cotton, palm oil, coconut, babassu and, especially, castor oil, may be used in the near future, once their cultivation could achieve an economic up-scaling. The alcohol source in general is methanol. In Brazil, ethanol from sugar cane has a great potential as an alcohol source, since it may ally its non toxicity with a ready availability. But, it is less reactive than methanol and there are some technological problems in its industrial use.

The possibility of using vegetable oils as fuel has been recognized since the beginning of diesel engines. In 1911, Rudolph Diesel presented an engine based on compression-ignition: the diesel engine. At that time there was no specific fuel to feed this engine. Rudolph Diesel used groundnut oil. In the preface of the book Thermodynamics, (Chalkey, 1911), ${ }^{1}$ Rudolph Diesel wrote that the diesel engine could be fed by vegetable oils, and that this possibility could help the agricultural 
development in the countries where this engine would be used.

Esters from vegetable oils are the best substitutes for diesel because they do not demand any modification in the diesel engine and have a high energetic yield. Besides, vegetable oils naturally fix the solar energy and do not contain sulphur.

\subsection{Vegetable oils as fuel for diesel engines}

All research focusing on the use of vegetable oils to feed diesel engine showed coking and trumpet formation on the injectors to such an extent that fuel atomization does not occur properly or is even prevented. There have been many problems associated with using vegetable oils directly in diesel engines, problems such as: decrease in power output and thermal efficiency of the engine; ${ }^{2}$ carbon deposits; oil ring sticking; thickening or gelling of the lubricating oil as a result of contamination by vegetable oils. Other disadvantages to the use of vegetable oils and especially animal fats are the high viscosity (about 11-17 times higher than diesel fuel) and lower volatility that result in carbon deposits in engines due to incomplete combustion. ${ }^{3}$ Beside that, vegetable oils contain polyunsaturated compounds. Some chemical or physical modifications have been tested to overcome these problems: pyrolysis, microemulsification, dilution and transesterification.

The pyrolysis of fats has been investigated for more than 100 years, especially in areas without deposits of petroleum. Copra oil and palm oil stearin were chacked over $\mathrm{SiO}_{2} / \mathrm{Al}_{2} \mathrm{O}_{3}$ at $450{ }^{\circ} \mathrm{C}$ to produce "biodiesel" fuels. The chemical compositions of diesel fractions were similar to fossil fuels. ${ }^{4}$ Pyrolyzed soybean oil has $79.0 \%$ of carbon and $11.9 \%$ of hydrogen. ${ }^{5}$ Its cetane number (43) is higher than the oil cetane number (37.9) and its viscosity (10.2 cSt at $38^{\circ} \mathrm{C}$ ) is lower than the vegetable oil viscosity (32.6 cSt at $\left.38^{\circ} \mathrm{C}\right)$. Nevertheless, this value is higher than that required for diesel $(7.5 \mathrm{cSt})$. Pyrolysed oils have acceptable levels of sulphur, water and particulate matter. Otherwise, they have unacceptable levels of ashes and carbon deposits and high pour point.

Microemulsions can be prepared from vegetable oils, esters and co-solvents (dispersing agent), or from vegetable oils, alcohol and surfactants, blended or not with fossil diesel. Microemulsions improve spray characteristics by explosive vaporization of the low boiling constituents in the micelles. ${ }^{6}$ Microemulsions from vegetable oils and methanol have a performance similar to diesel. ${ }^{7}$ 2-Octanol is an effective amphiphilic in the micellar solubilization of methanol in triolein and soybean oil. This system viscosity is $11.2 \mathrm{cSt}$ at $25^{\circ} \mathrm{C}$.
E-diesels (blends of ethanol in diesel) are currently being used in fleet vehicles in the European Union and the United States. Studies carried out with E-diesel indicated significant reductions of particulate matter (PM), sometimes up to $40 \%$, depending on the test methods and operating conditions. ${ }^{8}$ The $\mathrm{CO}$ and nitrogen oxides $\left(\mathrm{NO}_{\mathrm{x}}\right)$ emissions were significantly lower when a $20 \%$ blend of E-diesel was used in a constant-speed stationary diesel engine, as opposed to diesel fuel. ${ }^{9}$ The addition of ethanol to diesel may result in a volumetric reduction in sulphur, by as much as $20 \%$, thus significantly reducing $\mathrm{SO}_{2}$ emissions. ${ }^{9}$ The major drawback in E-diesel is that ethanol is immiscible in diesel over a wide range of temperatures. ${ }^{10}$

The viscosity of a mixture of sunflower oil and diesel $\left(1: 3 \mathrm{v} / \mathrm{v}\right.$ ) is $4.88 \mathrm{cSt}$ at $40^{\circ} \mathrm{C}$ (maximum specified ASTM value is $4.0 \mathrm{cSt}$ at $\left.40{ }^{\circ} \mathrm{C}\right) .{ }^{11}$ The mixture is not suitable for long term use in diesel engines. A blending of diesel and safflower oil (high level of oleic acid) was tested resulting in a good performance, but its long term use is not recommendable because of lubricant thickening. A blending of soybean oil and solvent $(1: 1 \mathrm{v} / \mathrm{v}$; solvent composition: $48 \%$ paraffins and $52 \%$ naphthalenes) has a viscosity of $5.12 \mathrm{cSt}$ at $38{ }^{\circ} \mathrm{C}$, and generate heavy carbon deposits and wearing on the engine upper ring.

Transesterification is widely used to reduce vegetable oil viscosity. Most industrial processes employ alkaline catalysis $^{12}$ and methanol. In almost all countries methanol is more available than ethanol.

The transesterification process reduces the molecular weight to $c a .1 / 3$ in relation to the triglycerides, and also, reduces the viscosity and improves the volatility. After the reaction, the products are a mixture of esters of fatty acids, glycerol, alcohol, catalyst and a low percentage of tri-, diand monoglycerides. Pure biodiesel fuel (100\% esters of fatty acids) is called B100. When blended with diesel fuel the designation indicates the amount of B100 in the blend, e.g. B20 is $20 \% \mathrm{~B} 100$ and $80 \%$ diesel, and B5 used in Europe is contains 5\% B100 in diesel.

\section{A General View About Research On Biodiesel}

A search of scientific articles and patents on biodiesel was undertaken to get a general view about this issue. The search focused on the last 5 years (2000 to September 2004) and it used "biodiesel" as the keyword. The following databases were accessed:

Scientific articles: (i) Scielo (database developed by FAPESP, BIREME and CNPq) - www.scielo.br, (ii) American Chemical Society - www.pubs.acs.org, (iii) Elsevier www.sciencedirect.com 
Patents: (i) Brazilian Office (INPI) - www.inpi.gov.br, (ii) European Office - ep.espacenet.com, (iii) American Office - www.uspto.gov

134 scientific articles and 84 published and/or issued patents were found. The information shown in items 2 and 3 is based on these articles and patents.

The grown interest in biodiesel may be testified by the number of scientific articles and patents (Figure 1).

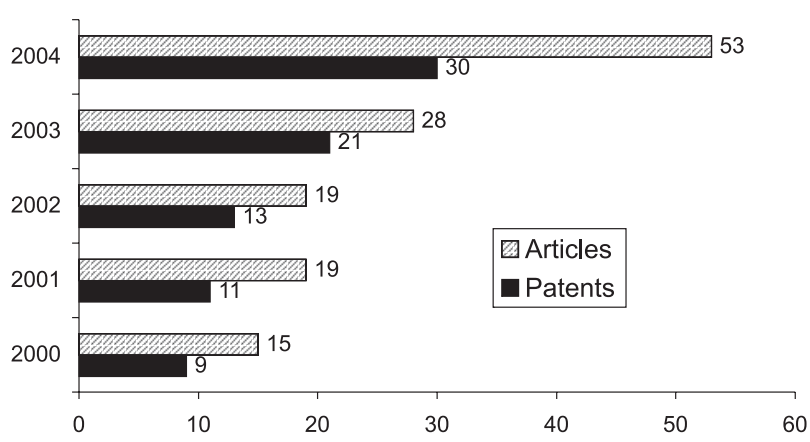

Figure 1. Number of articles and patents on biodiesel since 2000 .

Consulting The Journal of Citation Reports (1997) it was found that $19.4 \%$ of articles were published in journals whose Impact Factor (IF) was not defined; 37.3\% in journals whose IF was between $0-1 ; 33.6 \%$ in journals whose IF was between $1-2$; and $9.7 \%$ in journals whose IF was up to 3 .

The search for patents in Industrial Property Offices was focused on Brazilian, American and European Offices (Figure 2). At the Brazilian Office (INPI), 9 registers of patent were found since 2000, but only one issued patent. At the American Office (USPTO), 12 issued patents were found since 2000, and there are 14 published patents. The European Office shows all patents in the European Union and all patent documentation received from other Industrial Property Offices. All these data formed a group of 84 patents that, together with the articles, was used as reference for this topic and the next. It is important to say that among the patents there are INPADOC families.

A patent can be a tool to protect an interesting market. The number of patents at a specific Industrial Property Office reveals the power of this market concerning the technological area protected by the patent (Figure 2). Some patents are submitted on the PCT: Patent Cooperation Treaty. This treaty is signed by about 125 members' states and allows to invoke the protection for an invention in the main countries of the world, by means of a single application.

Universities are the institutions that devote more attention to write scientific articles about biodiesel. Among the 134 scientific articles analyzed, 86 were from universities; 26 from universities in collaboration with

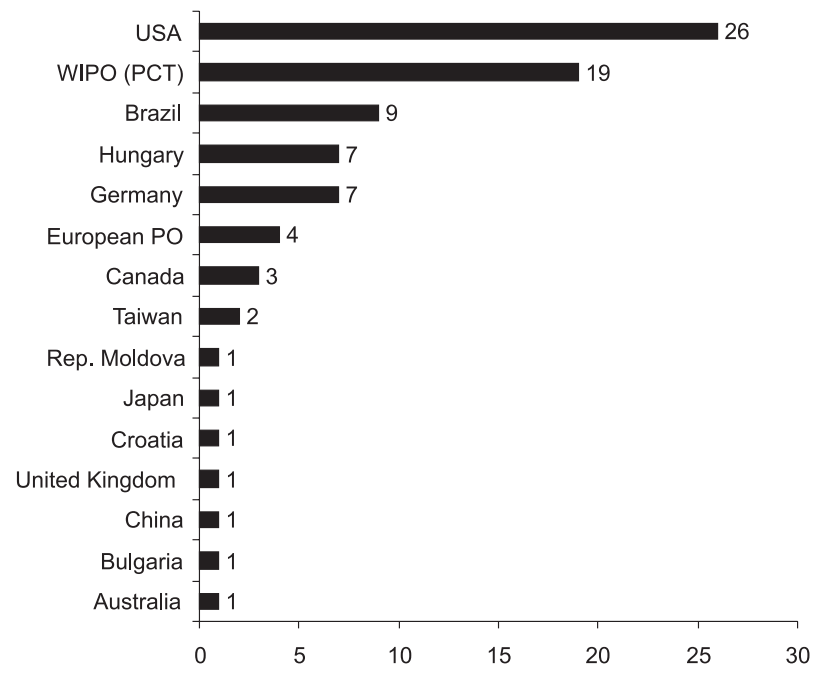

Figure 2. Number of patents on biodiesel since 2000, classified by Country Industrial Property Offices.

research centres or industries, and 22 from research centres in collaboration with industries. On the other hand, among 84 patents, only three have universities as applicant.

\subsection{Worldwide research on biodiesel in the last five years}

USA has prominence in almost all technological and scientific areas. This scenery is the same concerning the production of patents and scientific articles on biodiesel (Figure 3).

It is remarkable the effort made by Germany to reach a high scientific and technological level in biodiesel production. The German eminence in this topic is due, among other factors, to the absence of active petroleum deposits in this country and to the governmental support to new technologies based on renewable sources.

\section{Source for Biodiesel Production}

The source for biodiesel production is chosen according to the availability in each region or country. Any fatty acid source may be used to prepare biodiesel, but most scientific articles take soybean as a biodiesel source (Figure 4). Since the prices of edible vegetable oils, as soybean oil, are higher than that of diesel fuel, waste vegetable oils and non-edible crude vegetable oils are preferred as potential low priced biodiesel sources. Low-quality underused feedstocks have been used to produce biodiesel. This product is comparable in composition, similar in engine performance and emissions, and predicted to be more economical to produce than biodiesel from refined soybean oil. ${ }^{13}$

There are various other biodiesel sources: almond, ${ }^{14}$ andiroba (Carapa guianensis), ${ }^{15}$ babassu (Orbignia sp.), ${ }^{15-17}$ 


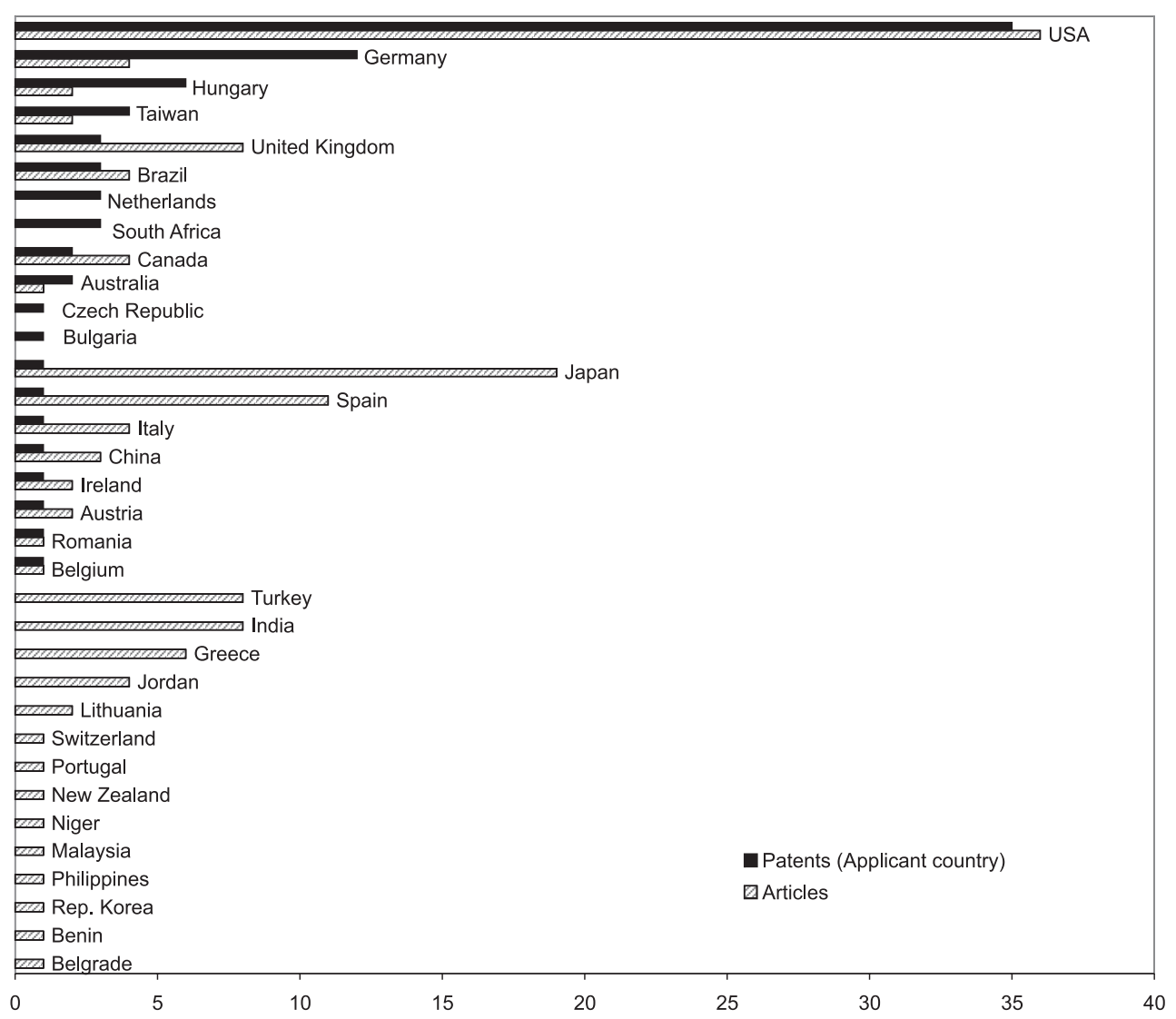

Figure 3. Number of scientific articles and patents about biodiesel classified by country.

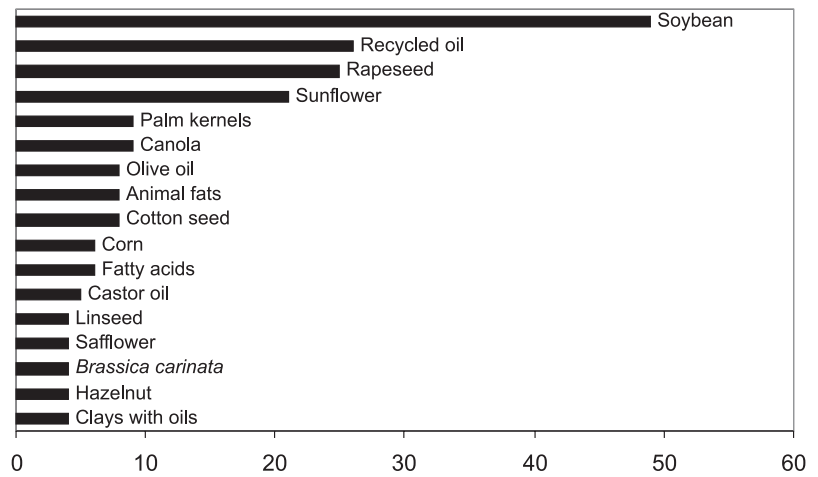

Figure 4. Leading biodiesel sources cited in scientific articles.

barley, ${ }^{18}$ camelina (Camelina sativa),${ }^{19}$ coconut, ${ }^{13,20}$ copra, ${ }^{21}$ cumaru (Dipteryx odorata), ${ }^{15}$ Cynara cardunculus, ${ }^{22}$ fish oil, ${ }^{17,23}$ groundnut, ${ }^{13,16,17,21}$ Jatropha curcas, ${ }^{24,25}$ karanja (Pongamia glabra) ${ }^{26}$ laurel, ${ }^{13}$ Lesquerella fendleri,${ }^{27}$ Madhuca indica, ${ }^{28}$ microalgae (Chlorella vulgaris) ${ }^{29}$ oat, ${ }^{18}$ piqui (Caryocar sp.), ${ }^{15}$ poppy seed, ${ }^{13,30,32}$ rice, ${ }^{18,21,23}$ rubber seed, ${ }^{31,32}$ sesame, ${ }^{13}$ sorghum, ${ }^{18}$ tobacco seed,${ }^{33}$ wheat. ${ }^{18}$

From a chemical point of view, oils from different sources have different fatty acid compositions. The fatty acids are different in relation to the chain length, degree of unsaturation or presence of other chemical functions (Table 1). Esters prepared with long chain fatty acid or saturated fatty acid show higher cetane number, higher cloud point and cause nozzle clogging. Esters prepared with very unsaturated fatty acid show low cetane number and suffer oxidation easily. Generally, cetane number, heat of combustion, melting point and viscosity of neat fatty compounds increase with increasing chain length and decrease with increasing unsaturation.

Biodiesel properties are strongly influenced by the properties of the individual fatty esters. It therefore appears reasonable to enrich it with certain fatty esters with desirable properties in the fuel in order to improve the properties of the whole fuel. It may be possible in the future to improve the properties of biodiesel by means of genetic engineering of the parent oils, which could eventually lead to a fuel enriched with certain fatty acids, possibly oleic acid, that exhibits a combination of improved fuel properties. ${ }^{34}$

A suitable source to produce biodiesel should not compete with others applications that reach higher prices, for example pharmaceutical raw material. But the demand for pharmaceutical raw material is lower than for fuel sources. The selection of a source for fuel production must take into consideration the characteristics of oil market (Figure 5). 
Table 1. Fatty acid composition of some vegetable oils (\%)

\begin{tabular}{|c|c|c|c|c|c|c|c|}
\hline Vegetable Oil & $\begin{array}{l}\text { Palmitic } \\
\text { 16:0 }\end{array}$ & $\begin{array}{c}\text { Stearic } \\
18: 0\end{array}$ & $\begin{array}{c}\text { Palmitoleic } \\
16: 1\end{array}$ & $\begin{array}{l}\text { Oleic } \\
18: 1\end{array}$ & $\begin{array}{c}\text { Linoleic } \\
18: 2\end{array}$ & $\begin{array}{c}\text { Ricinic } \\
\text { 12-OH-oleic }\end{array}$ & $\begin{array}{l}\text { Other } \\
\text { acids }\end{array}$ \\
\hline Tallow & 29.0 & 24.5 & - & 44.5 & - & - & - \\
\hline Coconut oil & 5.0 & 3.0 & - & 6.0 & - & - & 65.0 \\
\hline Olive oil & 14.6 & - & - & 75.4 & 10.0 & - & - \\
\hline Groundnut oil & 8.5 & 6.0 & - & 51.6 & 26.0 & - & - \\
\hline Cotton oil & 28.6 & 0.9 & 0.1 & 13.0 & 57.2 & - & 0.2 \\
\hline Corn oil & 6.0 & 2.0 & - & 44.0 & 48.0 & - & - \\
\hline Soybean oil & 11.0 & 2.0 & - & 20.0 & 64.0 & - & 3.0 \\
\hline Hazelnut kernel & 4.9 & 2.6 & 0.2 & 81.4 & 10.5 & - & 0.3 \\
\hline Poppy seed & 12.6 & 4.0 & 0.1 & 22.3 & 60.2 & - & 0.8 \\
\hline Rapeseed & 3.5 & 0.9 & 0.1 & 54.1 & 22.3 & - & 9.1 \\
\hline Safflower seed & 7.3 & 1.9 & 0.1 & 13.5 & 77.0 & - & 0.2 \\
\hline Sunflower seed & 6.4 & 2.9 & 0.1 & 17.7 & 72.8 & - & 0.1 \\
\hline Castor oil & - & 3.0 & 3.0 & 3.0 & 1.2 & 89.5 & 0.3 \\
\hline
\end{tabular}

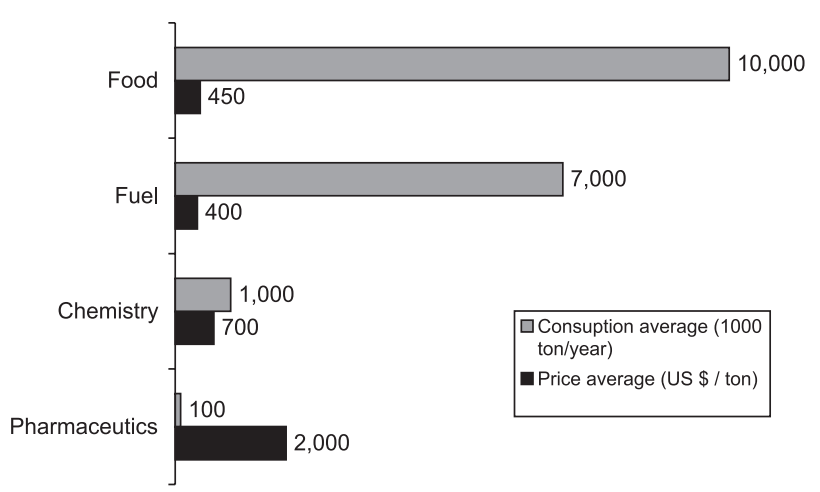

Figure 5. Characteristics of oil market.

As much as possible the biodiesel source should fulfil two requirements: low production costs and large production scale. Refined oils have high production costs, but low production scale; on the other side, seeds, algae and sewerage have low production costs and are more available than refined or recycled oils.

To elect a biodiesel source it is necessary also to take into consideration the oil percentage in the plant and the yield of oil per hectare (Figure 6). The palm kernel, for example, has a great potential as a biodiesel source, and has been used by several countries (Malaysia, for example).

In Brazil, biodiesel production has been adjusted to the available crop in each region (Figure 7). In the North, palm kernel and soybean are the most used sources; in the Northeast, castor bean, palm oil, palm kernel, babassu, soybean and cotton seed; in the Central-West, soybean, cotton seed, castor bean and sunflower seed; in the Southeast, soybean, castor bean, cotton seed and sunflower seed; in the South, sunflower seed, soybean, rapeseed and cotton seed.

Soybean occupies a special place among the oil plants that grow in Brazil. This leguminous plant is cultivated in

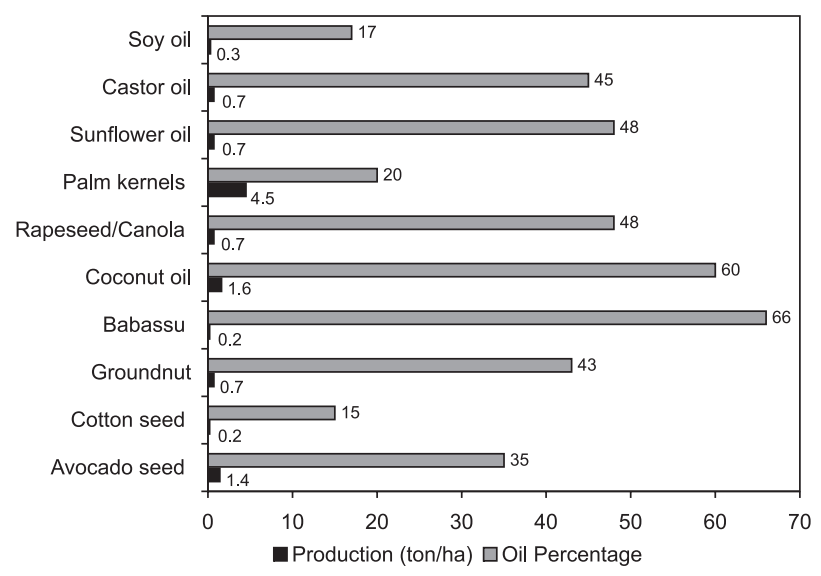

Figure 6. Oil percentage and production.

many states of the country and is responsible for $c a .90 \%$ of the total of produced vegetable oils. Its participation in the market is mainly related to exportation of seeds in natura and it is an important source of exchange value to Brazil. However, if the exported commodities were refined oil and tart, surely more value could be associated to the exported products.

Soybean and castor seed, because of the large agriculture areas, and palm, especially because of the high level of oil, provide excellent options for expansion of vegetable oil production in Brazil. In the Northeast of Brazil, besides palm, sunflower, cotton and soybean, we could highlight castor seed, which can be cultivated in all states. Nevertheless, a castor seed has presented low productivity, between 600 and $1,000 \mathrm{~kg} / \mathrm{ha}$ year. Studies show that this yield could reach $3,000 \mathrm{~kg} / \mathrm{ha}$ year with genetic improvement and with possible introduction of irrigated cultivation. ${ }^{35}$ Palm oil (Elaeis guineensis) is an important alternative for the sustainable development of some regions of Brazil, including Amazônia.

Ferrari et al. ${ }^{36}$ presented a process for biodiesel production by the transesterification of neutral soybean oil and 


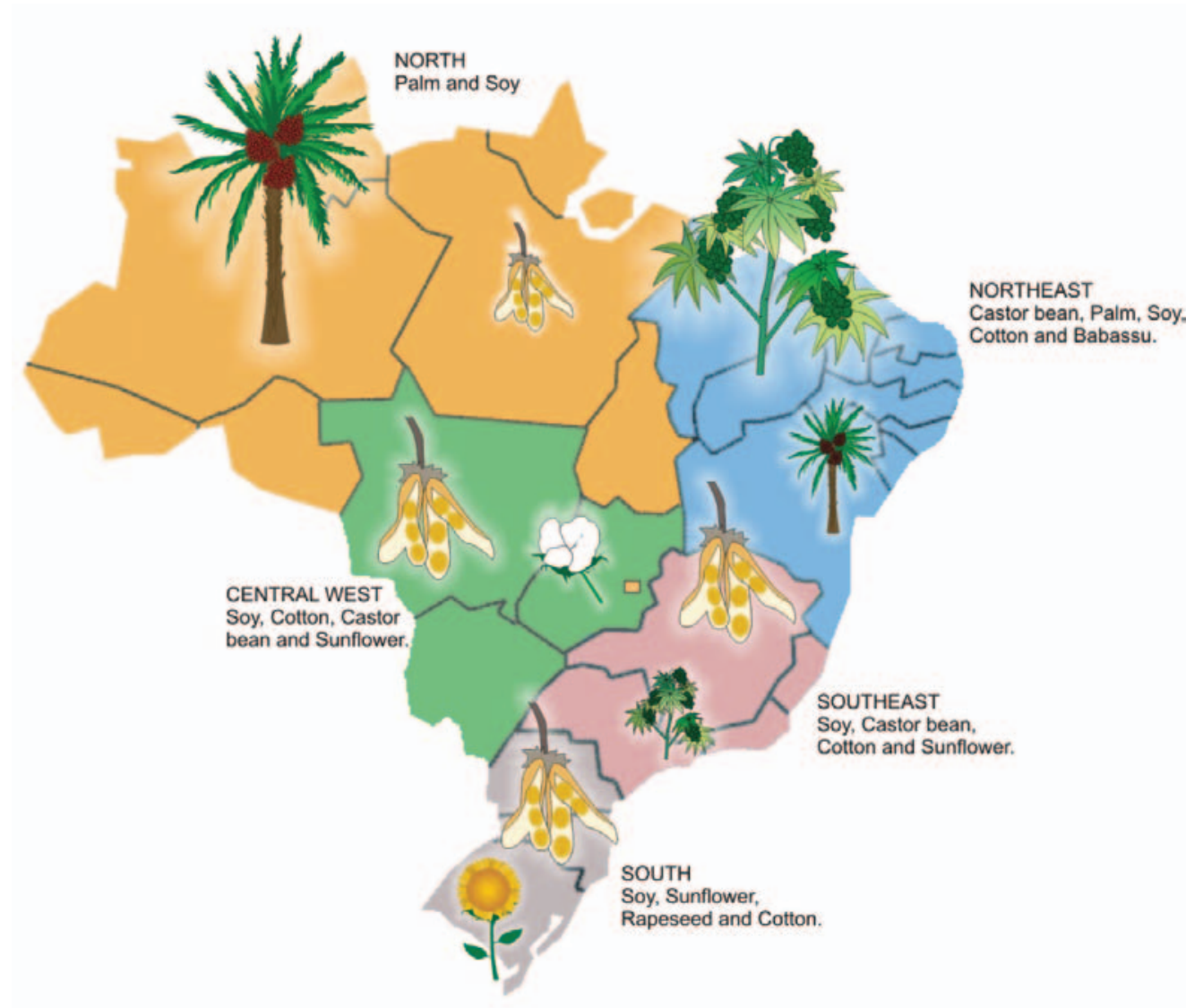

Figure 7. Biodiesel sources according to Brazilian regions.

anhydrous ethanol using $\mathrm{NaOH}$ as catalyst. Combinations of biodiesel and diesel in the proportions of 0, 5, 10, 20, 40, 60,80 and $100 \%$ were tested as fuel in an energy generator. The average consumption and mixture performance were analyzed. The tests showed a reduction in diesel oil consumption when mixed with up to $20 \%$ of biodiesel.

\section{Development of New Catalysts for Biodiesel Production}

The preparation of biodiesel is generally carried out using vegetable oils or animal fats as a starting material. The transesterification reaction is preferred to the direct esterification of fatty acid because triglycerides are more available than free fatty acids. Biodiesel is produced by transesterification of the triglycerides with short chain alcohols in the presence of a suitable catalyst. The reaction is shown in Scheme 1. The stoichiometry requires $3 \mathrm{~mol}$ of alcohol and $1 \mathrm{~mol}$ of triglyceride to give $3 \mathrm{~mol}$ of fatty acid esters and $1 \mathrm{~mol}$ of glycerine. The overall process is a sequence of three consecutive reversible reactions where diglyceride and monoglyceride are intermediate products.

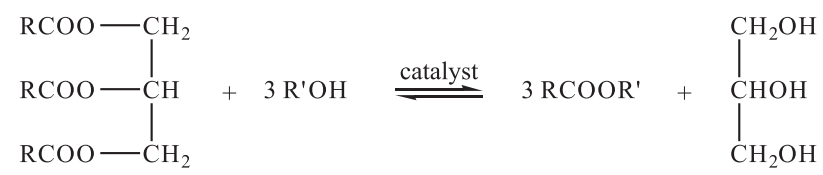

Scheme 1. Transesterification reaction of triglyceride.

The transesterification reaction can be catalyzed by both acid and alkaline catalysts, using a homogeneous or heterogeneous catalytic process. Sodium and potassium hydroxide are commonly used as industrial catalysts, since they are relatively cheap and also very active. ${ }^{2}$ On the other hand, their utilization in vegetable oil transesterification produces soaps by neutralizing the free fatty acid in the oil and by triglyceride saponification. The soap formation is an undesirable side-reaction, because it partially consumes the catalyst, decreases the biodiesel yield and complicates the separation and purification steps. ${ }^{37}$ The removal of these catalysts is technically difficult and brings extra cost to the final product. In addition, the difficulty for recycling and the generation of large waste amounts make the traditional catalysts less favourable.

More recently, there has been an increasing development of new catalysts for biodiesel production. According to Web 
of Science Database, 320 articles were found using "biodiesel" as the keyword in the period from 2000 to September 2004. A total of 80 articles focused on biodiesel production. From these, 67 articles reported production by transesterification reaction and 12 articles by esterification. The research showed that enzyme is the most studied catalyst in the last years and few studies have been conducted without a catalyst. The types of catalyst used in the transesterification process is presented in Figure 8.

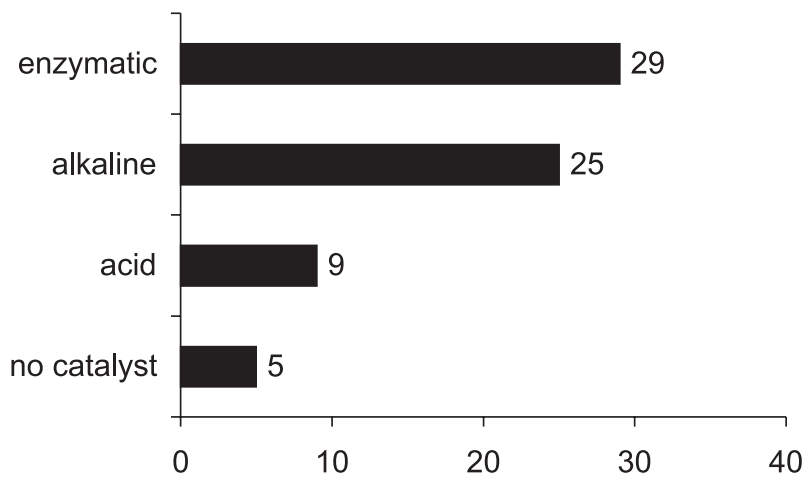

Figure 8. Number of articles on transesterification catalysts.

It could be observed that there are more articles about heterogeneous processes than homogeneous processes (Figure 9).

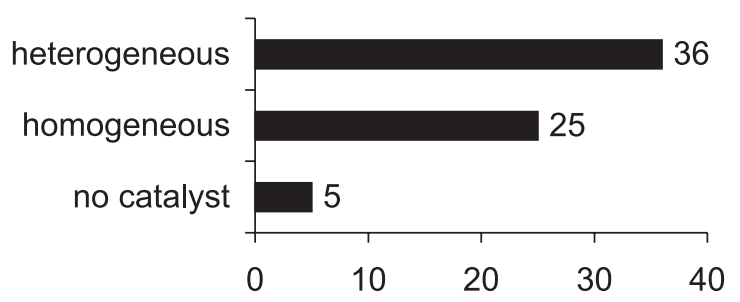

Figure 9. Number of articles for processes studied.

Finally, the number of articles, according to approaches on different types of heterogeneous catalysts are presented in Figure 10. It clearly shows the increasing use of enzymes as catalyst.

The uses of different available catalysts for the preparation of biodiesel are reviewed. Special attention is given to the recently developed catalysts. Firstly, we will focus on acid and alkaline catalysts for homogeneous processes (section 4.1). Then, new acid and alkaline catalysts will be mentioned for heterogeneous processes (section 4.2).

\subsection{Catalysts for homogeneous processes}

There are a number of reviews in the literature on alcoholysis of triglycerides using conventional homogeneous catalysts. ${ }^{2,16,37,38-41}$ The alkali catalyzed

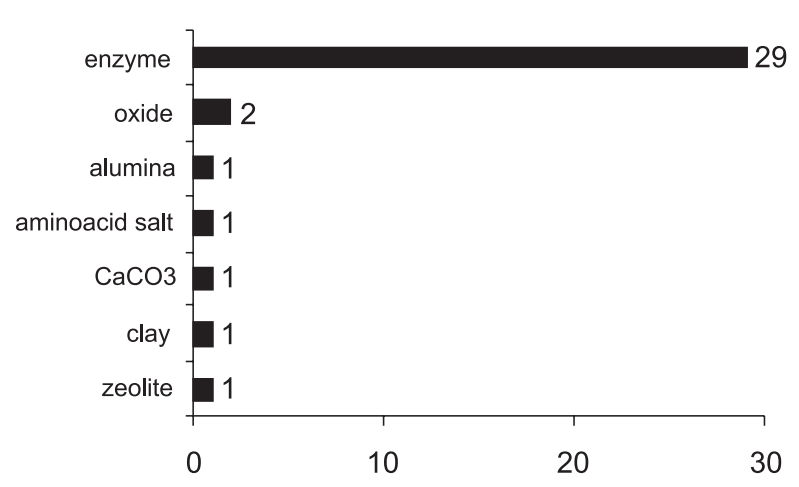

Figure 10. Number of articles for different heterogeneous catalysts.

transesterification of triglycerides is fast and high conversions are easy to achieve at temperatures from 40 to $65^{\circ} \mathrm{C}$. In addition, alkaline catalysts are less corrosive than acidic compounds. The alkaline processes are generally catalyzed by sodium alkoxides, sodium or potassium hydroxides as well as sodium or potassium carbonates. The alkoxide catalysts are more expensive than metal hydroxides. They are more difficult to manipulate since they are very hygroscopic and have only the hydroxide ion as impurity. In this sense, they do not produce soap through triglyceride saponification. The soap formation can also be avoided by using an acid catalyst. Sulphuric, hydrochloric and organic-sulphuric acids are usually preferred. The acids catalyze the free fatty acid esterification to produce fatty acid esters, increasing the biodiesel yield. Nevertheless, the acid catalyzed transesterification is much slower than the alkali catalyzed reaction and also needs more extreme temperature and pressure conditions.

There are few articles about the development of new catalysts for homogeneous processes. In 1995, a study reported the activity and efficiency of guanidine and eight substituted cyclic and acyclic guanidines as catalysts for the transesterification of rapeseed oil. ${ }^{42}$ The best result showed that only $1 \mathrm{~mol} \%$ of 1,5,7-triazabicyclo[4,4,0]dec-5-ene (TBD) produces more than $90 \%$ of methyl esters after $1 \mathrm{~h}$.

In 2003, metal complexes of the type M(3-hydroxy-2methyl-4-pyrone $)_{2}\left(\mathrm{H}_{2} \mathrm{O}\right)_{2}$, where $\mathrm{M}=\mathrm{Sn}, \mathrm{Zn}, \mathrm{Pb}$ and $\mathrm{Hg}$, were used for soybean oil methanolysis under homogeneous conditions. ${ }^{43}$ The $\mathrm{Sn}$ and $\mathrm{Zn}$ complexes showed great activities for this reaction, achieving yields of up to 90 and 40\%, respectively, in $3 \mathrm{~h}$ using molar ratio 400:100:1 (methanol:oil:catalyst), without emulsion formation. Recently, the same researchers studied the catalyst behaviour of these complexes in the transesterification of different triglyceride sources. The methanolysis of Brazilian oils such as andiroba, babassu, cumaru, palm, piqui and soybean oils were investigated. The catalytic system formed by the tin complex always presents higher conversion than the others. ${ }^{15}$ 


\subsection{Catalysts for heterogeneous processes}

Although transesterification using a conventional alkali catalyzed process gives high conversion levels of triglycerides to their corresponding methyl esters in short times, the reaction has several drawbacks: it is energy intensive; recovery of glycerine is difficult; the catalyst has to be removed from the product; alkaline waste-water requires treatment and free fatty acids and water interfere with the reaction. ${ }^{39}$ In order to minimize homogeneous process problems, attempts to use heterogeneous catalyst systems in alcoholysis of triglycerides have been made. These catalysts greatly simplify the post-treatment of the products (separation and purification). They can be easily separated from the system at the end of the reaction and could also be reused. Besides, the use of heterogeneous catalysts does not produce soaps through free fatty acid neutralization or triglyceride saponification. ${ }^{37}$ However, the performance is still unfavourable compared to the alkaline homogeneous catalysts.

A large number of heterogeneous catalysts have been reported in the literature, including enzymes, zeolites, clays, guanidines heterogenized on organic polymers, ionexchange resins, oxides, etc. Some recent results will be summarized below.

The activity of guanidine-containing polymers and their homogeneous analogues was compared as catalysts in the transesterification of soybean oil with methanol. ${ }^{44}$ The methanol:oil molar ratio was three times higher in the reactions using the guanidine-containing polymers in order to assure low viscosity for the reaction mixture. The heterogeneous catalysts were used at $5 \mathrm{~mol} \%$ in contrast to the $3 \mathrm{~mol} \%$ used with the homogeneous catalyst. They are nearly as active as their homogeneous analogues and reached the same high conversions (>90\%) after prolonged reaction time. In addition, the use of polystyrene-bound biguanides as recyclable catalysts was showed for the transesterification of several vegetable oils. ${ }^{45}$ Yields above $90 \%$ were obtained in less than $15 \mathrm{~min}$. These catalysts were, by far, more reactive and more stable than the polystyrene-supported guanidines previously described.

Insoluble salts of amino acids were used as catalyst for the methanolysis of triglycerides. ${ }^{46}$ Some metal salts of amino acids such as those of copper, zinc, cadmium, nickel, lanthanum, cobalt, calcium, magnesium and iron were tested. Zinc-arginate catalyzed the methanolysis of palm oil with high yield, with a methanol:oil molar ratio of $6: 1$. Reasonable reaction rates could be achieved at temperatures higher than $130{ }^{\circ} \mathrm{C}$.

The transesterification of soybean oil using calcium carbonate as a catalyst was investigated. ${ }^{47}$ Conversions above
$95 \%$ are achieved at $260^{\circ} \mathrm{C}$ for ethyl esters, using flow reactors and $18 \mathrm{~min}$ as residence time. No decrease in the activity of calcium carbonate was observed after weeks of utilization.

The methanolysis of rapeseed oil was tested in the presence of cesium-exchanged $\mathrm{NaX}$ faujasites, mixed magnesium-aluminum oxides, magnesium oxide and barium hydroxide as catalysts for different methanol:oil ratios. ${ }^{48}$ Barium hydroxide was particularly effective for a methanol:oil molar ratio of 6:1, at reflux of methanol and after a reaction time of only $1 \mathrm{~h}$. The oil conversion was about $80 \%$ with a nearly quantitative ester molar fraction. On the other hand, cesium-exchanged $\mathrm{NaX}$ faujasites and mixed magnesium-aluminum oxides required a long reaction time and a high methanol:oil molar ratio to achieve high yields in methyl esters. Recently, the transesterification of soybean oil with methanol in the presence of a series $\mathrm{NaX}$ faujasite zeolite, ETS-10 zeolite and metal catalysts were studied. ${ }^{49}$ A 6:1 molar ratio of alcohol and a $10 \% \mathrm{~m} / \mathrm{v}$ of catalyst were used at 60,120 and $150{ }^{\circ} \mathrm{C}$. The ETS-10 catalysts provided higher conversions $(>80 \%)$ than the zeolite-X type catalysts.

$\mathrm{Na} / \mathrm{NaOH} / \mathrm{g}-\mathrm{Al}_{2} \mathrm{O}_{3}$ heterogeneous alkaline catalysts were applied for the transesterification of soybean oil with methanol using hexane as co-solvent. ${ }^{50}$ The best result ( $>90 \%$ ) was obtained after $2 \mathrm{~h}$ using a methanol:oil molar ratio of $9: 1$ at $60{ }^{\circ} \mathrm{C}$. Monteiro and $\mathrm{Cruz}^{51}$ studied the transesterification of soybean oil using mixed oxides as catalysts. The reactions were carried out using a weight ratio of 4.5:6.0:0.3 (methanol:soybean oil:catalyst) at 70 ${ }^{\circ} \mathrm{C}$ for $8 \mathrm{~h}$. The following catalysts were investigated: $\mathrm{ZrO}_{2}-$ $\mathrm{SiO}_{2}, \mathrm{KOH} / \mathrm{ZrO}_{2}-\mathrm{SiO}_{2}, \mathrm{Co}_{2} \mathrm{O}_{3}-\mathrm{SiO}_{2}, \mathrm{Mo}_{2} \mathrm{O}_{5}-\mathrm{SiO}_{2}, \mathrm{Na}_{2} \mathrm{O}-\mathrm{SiO}_{2}$, $\mathrm{La}_{2} \mathrm{O}_{3}(10 \%)-\mathrm{MCM}-41, \mathrm{MgO}$ (10\%)-MCM-41, BaO (10\%)MCM-41, $\mathrm{CaO}$ and $\mathrm{MgO}$. Best results were obtained with $\mathrm{La}_{2} \mathrm{O}_{3}(10 \%)-\mathrm{MCM}-41, \mathrm{Na}_{2} \mathrm{O}-\mathrm{SiO}_{2}$ and $\mathrm{CaO}$, with conversions of $81 \%, 76 \%$ and $67 \%$, respectively.

The use of commercial sulfonic ion-exchange resin was also reported for production of biodiesel. ${ }^{52}$ The methanolysis of babassu and soybean oil was compared using Amberlyst-15 and sulphuric acid as a catalyst. The cationic-exchange resin showed better activity than the homogeneous catalyst.

The methanolysis of soybean oil was tested using tungstated zirconia-alumina (WZA), sulphated tin oxide (STO) and sulphated zirconia-alumina (SZA) as acid catalysts. ${ }^{53}$ The WZA catalyst was the most effective. After $20 \mathrm{~h}$, it achieved conversion higher than $90 \%$ at temperatures above $250{ }^{\circ} \mathrm{C}$.

Although the enzymatic process is still not commercially developed, a number of articles have shown that enzyme holds promise as catalyst. These studies consist mainly in optimizing the reaction conditions (temperature, 
alcohol:oil molar ratio, type of microorganism which generates the enzyme, enzyme amount, time, etc.) in order to establish the characteristics for industrial applications. Several studies have shown the possibility of recycling the catalyst but the reaction time is still unfavourable if compared to the alkali catalyzed homogeneous processes. Reaction conditions reported in the literature using enzymes are summarized in Table 2.

Other conditions such as $\mathrm{pH}$, use of solvent, use of immobilized or free enzyme and water content are also important in order to obtain higher conversions. ${ }^{60-62}$ An immobilized Candida antarctica lipase (Novozyme 435) was inactivated by shaking it in a mixture containing more than 1.5 molar equivalents of methanol to oil. ${ }^{63}$ However, when methanol was added stepwise, the conversion to methyl esters was almost complete (98.4\%). The enzyme could be reused 50 times without loss of activity. An even more dramatic increase of the lipase efficiency was shown when it was pre-treated by a consecutive incubation in methyl ester and oil prior to reaction. ${ }^{64}$ Candida antarctica (Novozyme 435) was pre-incubated in methyl oleate for $0.5 \mathrm{~h}$ and subsequently in soybean oil for $12 \mathrm{~h}$.

\section{Methods of Analysis for Characterization of Biodiesel}

The vegetable oil or animal fat source reflects basically on the composition and nature of fatty acids present in triglycerides. The type and concentration of fatty acid has an outstanding effect on biodiesel stability, which will influence its storage and also its oxidation. Thus, it is important to know the characteristics of the biodiesel to be produced. A number of methods to analyze biodiesel have been published. These methods are important to identify and quantify the fatty acid composition of the biodiesel source. Therefore, a search for scientific articles was carried out, focused on these methods, and a discussion of the advantages and disadvantages of the most commonly employed methods is shown below.

The following databases were accessed: Scielo, American Chemical Society and Elsevier Databases. From these databases, 134 articles were found using "biodiesel" as a keyword in the period from 2000 to September 2004.

The search showed that only $50.7 \%$ of the articles reported the methods employed for quantifying the fatty acid composition of biodiesel. Among 134 articles only 68 describe the method for biodiesel characterization. Gas Chromatography (GC) and High-Performance Liquid Chromatography (HPLC) are the most commonly employed methods (Figure 11).

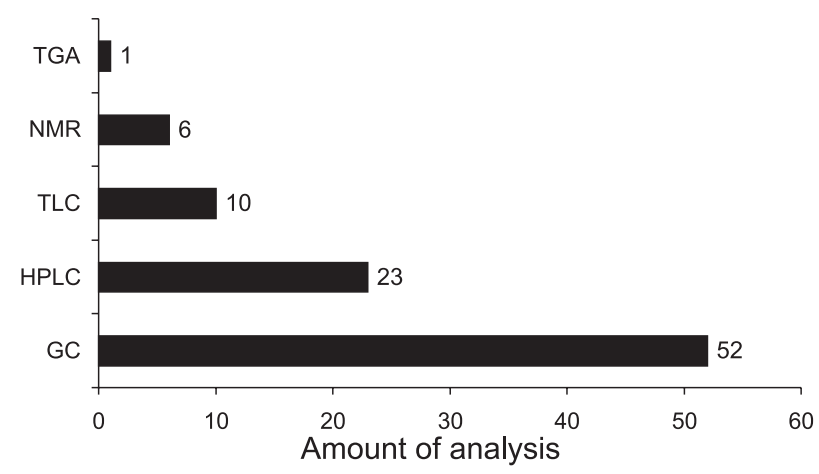

Figure 11. Number of articles by method used for the characterization of biodiesel.

\subsection{Comparison between GC and HPLC}

There is a large variety of analytical techniques for the detection, characterization and quantification of fatty acids (FAs) in biodiesel. The two most common analytical methods for studying fatty acids and triglycerides are GC and HPLC. The comparison of these two methods should focus not only the chromatographic analysis but also the sample preparation.

Although the application of HPLC to fatty acid analysis has increased over the last decade, GC is still the most widely used technique. ${ }^{65}$ This well-established procedure coupled with flame ionization detection (GC-FID) is very efficient and rapid when complex mixtures with a broad molecular range are analyzed. ${ }^{66}$

Fatty acids are suitable for separation, quantification and analysis by GC without any derivatization, as demonstrated by James and Martin. ${ }^{67}$ However, derivatization of fatty acids

Table 2. Summary of some studies using enzyme as catalyst

\begin{tabular}{|c|c|c|c|c|c|c|}
\hline Microorganism & Oil & Catalyst & Temp. $\left({ }^{\circ} \mathrm{C}\right)$ & time $(\mathrm{h})$ & Conversion $(\%)$ & Ref. \\
\hline Candida antarctica & soybean & $4 \mathrm{wt} \%$ & 30 & 3.5 & 97 & 54 \\
\hline Cryptococcus spp. S-2 & rice bran & $2000 \mathrm{U}$ & 30 & 120 & 80.2 & 55 \\
\hline Candida antarctica & soybean $^{\mathrm{a}}$ & $4 \mathrm{wt} \%$ & 30 & 48 & 93.8 & 56 \\
\hline Candida antarctica & cotton seed & $30 \mathrm{wt} \%$ & 50 & 7 & 91.5 & 57 \\
\hline Rhizopus oryzae & palm $^{\mathrm{b}}$ & $67 \mathrm{IU} \mathrm{g}^{-1}$ & 35 & 96 & 55 & 58 \\
\hline Rhizomucor miehei & soybean & 0.9 BAUN & 36.5 & 6.3 & 92.2 & 59 \\
\hline Chromobacterium viscosum & jatropha $^{\mathrm{c}}$ & $10 \mathrm{wt} \%$ & 40 & 8 & 92 & 24 \\
\hline
\end{tabular}

${ }^{a}$ Degummed oil. ${ }^{\mathrm{b}}$ From waste bleaching earth sample. ${ }^{\mathrm{c}}$ Ethanol was used instead of methanol. 
for GC analysis is performed to increase the volatility of the substances, to improve separation, and to reduce tailing. Recent developments in the technology of columns with bonded phases offer spectacular separation and little phase bleeding. Nevertheless, if a higher sensitivity is demanded, then derivatization is used. In recent times, GC has been used for the separation and analysis of geometric and positional isomers. Meanwhile, MS detection is a powerful technique for diagnostic fragmentation of saturated and unsaturated FAs, ${ }^{68}$ and analysis of branching positions in FAs. ${ }^{69}$

The major advantages of HPLC over GC are lower temperatures during analysis, which reduces the risk of isomerization of double bonds, and the possibility of collecting fractions for further investigation. ${ }^{70,71}$ The speed of analysis, selectivity and sensitivity are important parameters in HPLC that may be improved with derivatization.

Regarding the elution order of FAs, both methods are based on chain length and degree of unsaturation. FA retention times increase with carbon number. ${ }^{72}$

Regarding analysis time, sample preparation is much more time consuming in HPLC than in the GC method. Nevertheless this disadvantage is largely compensated by run time. ${ }^{72}$
The HPLC method is sensitive and precise and may be considered a good optional tool for the routine determination of 18:1 $\left(\Delta^{9}\right), 18: 2\left(\Delta^{9,12}\right)$ and 18:3 $\left(\Delta^{9,12,15}\right)$ in any oil. However, when a more complete study of FA profile is required, GC is the method of choice, since HPLC may present co-eluting peaks.

\subsection{Parameters of GC and HPLC analyses for quantifying biodiesel conversion}

Following the searches on the types of analysis employed for biodiesel characterization, some parameters were detached which are usually used in GC and HPLC. These parameters are presented in Table 3 for GC and Table 4 for HPLC.

\subsection{Parameters of ${ }^{1} H$ NMR and TLC analysis}

The final product of the transesterification can possess some traces of triglycerides which can damage some components of the GC equipment, for example the column. To avoid this problem, it is important to be sure about the conversion achieved by the transesterification of the vegetable oil.

Table 3. Summary of some parameters for analyzing biodiesel by GC

\begin{tabular}{|c|c|c|c|}
\hline Column: $1 \mathrm{x}$ id $\mathrm{x}$ ft (phase) & Injector Temp. $\left({ }^{\circ} \mathrm{C}\right)$ & Oven Temperature & Ref. \\
\hline $30 \mathrm{~m} \times 0.25 \mathrm{~mm} \times 0.25 \mu \mathrm{m}$ (polyethyleneglycol) & 250 & $\begin{aligned} 165-180{ }^{\circ} \mathrm{C} & \left(4{ }^{\circ} \mathrm{C} \mathrm{min} \mathrm{min}^{-1}\right) \\
180-200{ }^{\circ} \mathrm{C} & \left(5^{\circ} \mathrm{C} \mathrm{min}{ }^{-1}\right) \\
200-260{ }^{\circ} \mathrm{C} & \left(15^{\circ} \mathrm{C} \mathrm{min}-1\right) \\
260{ }^{\circ} \mathrm{C} & (2 \mathrm{~min})\end{aligned}$ & $73^{\mathrm{b}}$ \\
\hline $25 \mathrm{~m} \times 0.53 \mathrm{~mm} \times 1 \mu \mathrm{m}$ (acidified polyethylene glycol) & - & $180-200{ }^{\circ} \mathrm{C}\left(4^{\circ} \mathrm{C} \mathrm{min}{ }^{-1}\right)$ & 74 \\
\hline $25 \mathrm{~m} \times 0.32 \mathrm{~mm} \times 0.52 \mu \mathrm{m}$ (5\% diphenyl and $95 \%$ dimethyl polysiloxane) & 250 & $150-225{ }^{\circ} \mathrm{C} \quad\left(5^{\circ} \mathrm{C} \mathrm{min}{ }^{-1}\right)$ & $57^{\mathrm{c}}$ \\
\hline $30 \mathrm{~m} \times 0.32 \mathrm{~mm} \times 1 \mu \mathrm{m}$ & $300^{\mathrm{a}}$ & $\begin{array}{ll}190-215{ }^{\circ} \mathrm{C} & \left(6^{\circ} \mathrm{C} \mathrm{min}^{-1}\right) \\
215-300{ }^{\circ} \mathrm{C} & \left(3^{\circ} \mathrm{C} \mathrm{min}^{-1}\right)\end{array}$ & $59^{\mathrm{d}}$ \\
\hline
\end{tabular}

a Splitless. ${ }^{\mathrm{b}}$ FID $250{ }^{\circ} \mathrm{C} .{ }^{\mathrm{c}}$ FID $280{ }^{\circ} \mathrm{C} .{ }^{\mathrm{d}}$ FID $300{ }^{\circ} \mathrm{C}$.

Table 4. Summary of some parameters for analyzing biodiesel by HPLC

\begin{tabular}{llll}
\hline Column: - 1 x id (TM) & Mobile phase & Temp $\left({ }^{\circ} \mathrm{C}\right)$ & Ref. \\
\hline $250 \mathrm{~mm} \times 4.6 \mathrm{~mm}$ (STRODS-II) & methanol & 40 & $75^{\mathrm{a}}$ \\
$250 \mathrm{~mm} \times 4 \mathrm{~mm}$ (LiChro CART RP-C18) & hexane:isopropanol:methanol & - & $76^{\mathrm{a}, \mathrm{b}}$ \\
$300 \mathrm{~mm} \times 7.8 \mathrm{~mm}$ (GPC-Styragel) & toluene & - & $77^{\mathrm{a}, \mathrm{c}}$ \\
$300 \mathrm{~mm} \times 7.5 \mathrm{~mm}$ (GPC-Styragel 0.5) & tetrahydrofuran & $35-40$ & 78 \\
\hline
\end{tabular}

${ }^{\mathrm{a}} 1.00 \mathrm{~mL} \mathrm{~min}{ }^{-1} .{ }^{\mathrm{b}}$ Injection loop of $10 \mu \mathrm{L}$. ${ }^{\mathrm{c}}$ Injection loop of $500 \mu \mathrm{L}$.

Table 5. Solvent systems and detecting reagents parameters by TLC

\begin{tabular}{lll}
\hline Solvent system (v/v/v) & Detecting reagents & Ref. \\
\hline Hexane:ethyl acetate:acetic acid $(90: 10: 1)$ & iodine vapour & 24 \\
Isohexane:diethyl ether:acetic acid $(80: 20: 1)$ & ultraviolet light & 80 \\
Chloroform:petroleum ether $(1: 3)$ & - & 81 \\
Petroleum ether:diethyl ether:acetic acid $(85: 15: 1)$ & iodine vapour & 82 \\
Hexane:ethyl acetate:acetic acid $(90: 10: 1)$ & sulphuric acid: methanol $1: 1$ & 64 \\
\hline
\end{tabular}


${ }^{1} \mathrm{H}$ NMR spectroscopy is a method used to quantify the conversion of vegetable oils in methyl esters by transesterification reaction. ${ }^{79}$ The relevant signals chosen for integration are those of methoxy groups in the methyl esters at $3.7 \mathrm{ppm}$ (singlet) and of the $\alpha$-carbonyl methylene groups present in all fatty ester derivatives at $2.3 \mathrm{ppm}$. The latter appears as a triplet, so accurate measurements require good separation of this triplet from the multiplet at 2.1 ppm, which is related to allylic protons.

TLC is commonly used for qualitative analysis. It is fast and effective, and also can be used to verify the conversion of the oil during the reaction. After this previous analysis, the product can be quantified by GC. Some solvent systems and detecting reagents commonly used for evaluation of starting material conversion during the reaction are shown in Table 5.

\section{Biodiesel Production Technology}

Nowadays, the production of biodiesel in Brazil occurs mainly on an experimental scale with plants of small capacity (up to 1,000 $\mathrm{t} \mathrm{year}^{-1}$ ). However, units of medium scale of ca. 5,000 $\mathrm{tyear}^{-1}$ and of high capacity, up to $30,000 \mathrm{t}$ year $^{-1}$, are being built. The transesterification process in an industrial unit with $1,800 \mathrm{t}^{\text {year }}{ }^{-1}$ is described here: the vegetable oil, animal fat or recycled oil is stored and, after acid correction, is transferred to the principal reactor. In a second reactor, the catalyst $(\mathrm{KOH}$ or $\mathrm{NaOH})$ and the alcohol ( $\mathrm{MeOH}$ or $\mathrm{EtOH})$ are homogenized and transferred to the principal reactor. The reaction is completed in $40 \mathrm{~min}$, in temperatures between 30 and $40{ }^{\circ} \mathrm{C}$. The biodiesel (superior layer) is then separated from the raw glycerine (inferior layer) by decantation (on batch process) or by centrifugation (on continuous process). The inferior layer, beside raw glycerine, contains part of the alcohol that could be recovered and reused in the process. The raw glycerine could be purified and used, for example, in the cosmetic industry (Figure 12).

The separation step is one of the most important in the biodiesel production, since it is essential for the specification of the product according to legislation. The fuel should have similar characteristics to those of fossil diesel and, in case it does not reach the claimed specification, should be reprocessed. In order to assure the product purity and avoid engine and also environmental damage, levels of free fatty acid, alcohol, water, and glycerine should be at a minimum. The yield of biodiesel from the process can vary from 70 to $90 \%$ depending on the type of starting material, reagents and operational conditions. The transesterification is affected by alcohol:oil molar ratio, catalyst, temperature, reaction time and the content of water and free acids. ${ }^{2}$

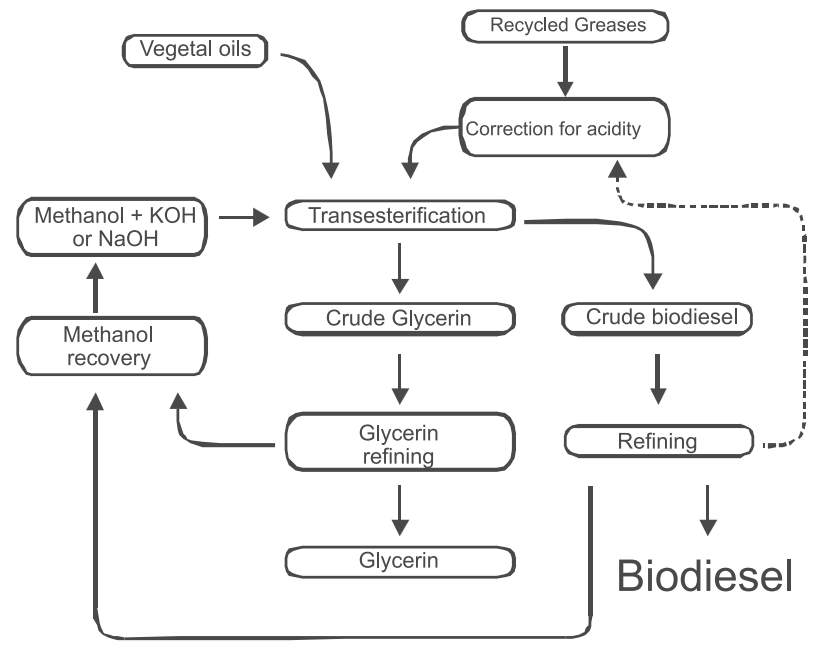

Figure 12. Schematic process for biodiesel production.

One of the most important variables affecting the yield of ester is the alcohol:oil molar ratio. The molar ratio is associated with the type of catalyst used. An acid catalyzed reaction needs a 30:1 ratio of $\mathrm{BuOH}$ :soybean oil, while an alkali catalyzed reaction requires only a $6: 1$ ratio to achieve the same ester yield for a given reaction time. Bradshaw and Meuly ${ }^{83}$ described that amounts of methanol above 1.75 equivalents tend to prevent the separation of the glycerine by gravity thus adding unnecessary expense to the process. Amounts of alcohol from 1.10 to 1.75 equivalents represent a practical range.

A continuous process of transesterification of triglycerides comprises bringing a stream of triglycerides into contact with a stream of alcohol in the presence of an alcoholysis catalyst. The continuous introduction of a stream of the liquid reaction product into a flash chamber, at low pressure, allows unreacted alcohol to flash into the vapour, and thus the remaining liquid contains only esters and glycerine. ${ }^{84}$

Transesterification can occur in different temperatures depending on the type of oil employed. The reaction of castor oil with methanol occurs most satisfactorily at temperatures in the range from 20 to $35^{\circ} \mathrm{C}$. At temperatures lower than $20^{\circ} \mathrm{C}$, the reaction proceeds so slowly as to be uneconomical. Higher temperatures than $35^{\circ} \mathrm{C}$ cause loss of catalyst due to saponification, and deleterious amounts of soap are formed. The reaction can be done using a alcohol:oil molar ratio from 6:1 to $12: 1$ and from 0.05 to $0.35 \%$ (in weight of oil) of $\mathrm{NaOH}$ as catalyst. ${ }^{85}$ Recently, many patents have been published, based on the transesterification route of vegetable oils or residual fats. ${ }^{86,87}$

In the 90's, some countries developed schemes to produce biofuels, using the methanol route and vegetable oil or residual fats as a starting material. In particular, Germany implemented a program for biodiesel production. 
The vegetable oil is extracted from rapeseed, which additionally fixes nutrients in the soil, in particular, nitrogen. In the extraction process, the seed is pressed and, beside the oil, tart is obtained as a by-product, which may be added to animal feed. The industrial units of biodiesel production, in Germany, have a high level of automation. However, they operate only during part of the year due to climatic conditions. There are over 1,000 gas stations for distribution of biodiesel. At the beginning, biodiesel was used mainly in vehicular fleet in big cities. The biodiesel price to the consumer is lower than fossil diesel. The difference can reach $12 \%$, and this can be explained by the reduction of governmental taxes. ${ }^{35}$

In France, for example, biodiesel also has been used in urban buses, in proportions up to $30 \%$ in fossil diesel (B30), in order to decrease vehicle emissions in big cities. The biodiesel chain is encouraged with the adoption of governmental decisions like reduction of taxation.

In Brazil, there is already a government law establishing the use of $2 \%$ mixtures of biodiesel in petroleum diesel (B2) by $2008 .{ }^{88}$ After that, this proportion will rise to $5 \%$ (B5). This strategy has the advantage of decreasing vehicle emissions, without changes in diesel engines.

\section{Emissions}

Increasing concern about combustion related pollutants, such as particulate matter (PM), sulphur and nitrogen oxides, $\mathrm{CO}$, metals, total organic carbon and volatile organic compounds (VOCs), amongst others, is driving governments to put more stringent requirements on fuel regulations. ${ }^{89}$

Exhaust emissions from diesel burning in motor vehicles contain hundreds of compounds, either in the gas or particulate phases. Several of those compounds are proved, or suspected to be, carcinogenics, such as formaldehyde, acrolein, PAHs, nitro-PAHs, benzene, sulphate, etc.

Amongst vehicular fuels, diesel also produces larger quantities of fine particulate matter, which consists basically of carbonaceous material, metals, soluble organic fraction (SOF) and sulphate. ${ }^{90}$ Epidemiological studies have associated the daily exposure to fine particulate matter $\left(\mathrm{d}_{\mathrm{p}} \leq 2.5 \mu \mathrm{m}\right)$ to mortality and morbidity. Also, statistical analysis has suggested that sulphate from fine particulate matter is very correlated to total mortality, ${ }^{91}$ while mutagenicity associated with the organic fraction of diesel emissions is largely dependent on the sulphur and aromatic content of the fuel. ${ }^{90}$

As a consequence, the use of alternative fuels in order to reduce the environmental impacts of diesel emissions has been extensively investigated. Trends in the regional use of biomass-derived fuels, such as alcohols, biodiesel and agricultural residues - as a proposed control initiative against elevated carbon monoxide levels in urban areas have expanded to a global scale. The general interest in biofuels obviously results from economic considerations but, more recently, increasing attention has also been due to the role that their combustion products may have on the question of global warming and on smog formation, as well as an alternative to substitute methyl tert-butyl ether as a gasoline additive.

The vehicular fleet in Brazil is quite unique in the world, as its light-duty vehicles, running in the largest cities, are fuelled with either a blend $22-24 \%$ (v/v) of anhydrous ethanol in gasoline - namely gasohol - or pure hydrated ethanol (95\%). At the beginning of the 90's, about $41 \%$ of the light-vehicles running, for example, in Salvador - the capital of Bahia, a big state in the north-eastern region of Brazil - were fuelled with pure hydrated ethanol, and that proportion was probably very similar to those in many other big Brazilian cities..$^{92}$ Meanwhile, in the middle of the 90 's, the atmospheric levels of ethanol measured in that city were in the range of 12.5 to $154.9 \mathrm{ppb}^{93}$

There is evidence that the use of alternative fuels such as ethanol, leads to an increase in the atmospheric levels of acetaldehyde. The acetaldehyde-to-formaldehyde ratios are well established in many works. ${ }^{94-96}$ The weighted aldehyde emission factors, for the ethanol vehicles operated under the urban driving cycle without catalytic converter, were in the range of 19 to $46 \mathrm{mg} \mathrm{km}^{-1}$ for formaldehyde and 143 to $246 \mathrm{mg} \mathrm{km}^{-1}$ for acetaldehyde. Immediately after the adoption of the use of converters, substantial reductions were observed, although the acetaldehyde emissions remained higher than formaldehyde. ${ }^{97}$

Volatile organic compounds (VOCs) play a significative role in the formation process of photochemical smog. Photooxidants are formed in the atmosphere when VOCs react with nitrogen oxides $\left(\mathrm{NO}_{\mathrm{x}}\right)$, in the presence of sunlight and $\mathrm{OH}$ radicals. In urban areas, vehicle fuels constitute an important source of VOCs and $\mathrm{NO}_{\mathrm{x}}$ emissions to the atmosphere, either by burning or evaporative losses. A comparative study of the two types of light-duty vehicular fuels presently used in Brazil - gasohol and hydrated ethanol - as potential precursors for ozone formation in the atmosphere of urban cities, was conducted outdoors, using two Teflon chambers which were filled, respectively, with each fuel, at high initial VOC to $\mathrm{NO}_{\mathrm{x}}$ ratios and exposed to the sunlight. Ozone formation, as well as $\mathrm{NO}_{x}$ concentration profiles were measured directly using ozone and $\mathrm{NO}_{x}$ continuous analyzers. The results showed that, for the same initial volumes of the two fuels into the bags, the ozone peak concentrations are on average $28 \%$ higher for alcohol 
compared with gasohol. In addition, the ozone formation process showed a tendency to start earlier for gasohol but, once started, its concentration increased up to two times faster than for alcohol fuel. ${ }^{98}$

From a perspective of the air quality in large urban centres, especially those to which public transportation is largely dependent on heavy-duty diesel vehicles, as is the case of the majority of Brazilian cities, several studies have pointed to the fact that biodiesel burning, either pure or in mixtures with diesel, can reduce the emissions of carbon monoxide (CO), particulate matter (PM), total hydrocarbons (THC) and sulphur compounds, although quite different conclusions can also be found related to other substances, since an increase in $\mathrm{NO}_{\mathrm{x}}$ and $\mathrm{SOF}$ (soluble organic fractions) emissions is also reported. ${ }^{99-108}$

Despite this, it is unquestionable that biodiesel has almost no sulphur and aromatics and, although $\mathrm{CO}_{2}$ emissions could be almost at the same levels as those of mineral diesel, its renewable characteristics by cultivation of vegetal sources make it a sink for the atmospheric $\mathrm{CO}_{2}$. On the other hand, available data for unregulated emissions and particle size characterization are still scarce for biodiesel, with only a few studies already done. ${ }^{109-111}$

Experiments conducted by Schumacher and Borgelt ${ }^{112}$ running on $100 \%$ biodiesel in a pickup, have shown increases of $13 \%$ in $\mathrm{NO}_{x}$ while PM decreased in $20 \%$, compared to pure diesel. Similar results were found by Chang et al., ${ }^{113}$ using blends of diesel with methyl and isopropyl esters of soybean oil. On the other hand Peterson and coworkers, ${ }^{114,115}$ in experiments conducted in the same way, have found a decrease of about $12 \%$ in $\mathrm{NO}_{\mathrm{x}}$ emissions, while PM emissions increased about $10 \%$ relative to pure diesel.

Puhan et al., ${ }^{116}$ during tests with blends of diesel and methyl esters of Madhuca indica seed oil, has concluded that emissions of $\mathrm{CO}, \mathrm{HC}$, smoke and $\mathrm{NO}_{\mathrm{x}}$ were reduced by $30 \%, 35 \%, 11 \%$ and $4 \%$ respectively, compared to diesel, although the fuel consumption was higher by $20 \%$. Raheman and Phadatare ${ }^{26}$ have compared pure diesel and blends with methyl ester of Karanja, a tree-borne nonedible seed oil, concluding that reductions in $\mathrm{CO}$, smoke and $\mathrm{NO}_{\mathrm{x}}$ emissions were, on an average, of $80 \%, 50 \%$ and $26 \%$ respectively, and that blends up to $40 \%$ by volume could replace diesel in engines, with less emissions.

Emissions of gases and particulate matter, from nine heavy-duty vehicles, fuelled with fossil diesel and a mixture of 35\% biodiesel in diesel (B35), were compared by Wang et al. ${ }^{100}$ Overall results for the emissions have shown, for B35, reductions in CO (12\%), THC and PM (25\%). The main factors contributing to these are, respectively, the higher oxygen content of B35, related to petroleum diesel, its higher cetane number and lower aromatic hydrocarbons and sulphur contents. For $\mathrm{NO}_{\mathrm{x}}$, on the other hand, emissions from B35 presented, compared to diesel, small increases or decreases, depending on the age of the engines. Formation of $\mathrm{NO}_{\mathrm{x}}$ is highly dependent on temperature and pressures inside the combustion chamber. High temperatures and pressures usually produced by biodiesel burning, along with its oxygen content, facilitate the $\mathrm{NO}_{\mathrm{x}}$ formation.

Despite a relatively large number of papers concerned with the emission comparison of regulated substances present in both fuels, much less are available with approaches related to unregulated substances.

Chemical and toxicological characteristics of biodiesel emissions were determined and compared with those of pure diesel, during experiments conducted with an urban bus engine, running with fossil diesel and mixtures of $20 \%$ methyl ester of rapeseed oil in fossil diesel (B20)..$^{90}$ The authors determined regulated and unregulated substances, such as polycyclic aromatic hydrocarbons (PAHs), nitroPAHs, carbonyl compounds and light aromatic hydrocarbons, either in vapour or particulate phases.

Regarding regulated substances, no significant differences were observed between both fuels. The determined emissions $\left(\mathrm{g} \mathrm{kW}^{-1} \mathrm{~h}^{-1}\right)$ for diesel and B20, were, respectively: THC $(0.6 \pm 0.1$ and $0.5 \pm 0.1)$; $\mathrm{CO}(2.1 \pm 0.2$ and $1.9 \pm 0.2) ; \mathrm{NO}_{\mathrm{x}}(5.3 \pm 0.3$ and $5.3 \pm 0.4) ; \mathrm{PM}(0.26 \pm$ 0.02 and $0.27 \pm 0.03$ ). Also, soluble organic fractions (SOF) were $49 \pm 1 \%$ for diesel and $52 \pm 12 \%$ for B20.

Regarding the unregulated substances, on the other hand, the sum of PAHs, both in vapour and particulate phases were higher for diesel, as expected since aromatics are virtually absent in biodiesel. The average emissions were, respectively, 9661 and $8416 \mathrm{ng} \mathrm{kW}^{-1} \mathrm{~h}^{-1}$, for diesel and B20 in particulate phase and 985 and $418 \mathrm{ng} \mathrm{kW}^{-1} \mathrm{~h}^{-1}$ in vapour phase. These values show a clear predominance of PAHs in particulate over vapour phase. Amongst the 10 PAHs determined in this work, beginning in the benz(a)anthracene, the most abundant was chrysene, with average emissions, in diesel and B20 respectively, of 3818 \pm 296 and 2920 \pm 1105 $\mathrm{ng} \mathrm{kW} \mathrm{kW}^{-1} \mathrm{~h}^{-1}$ in particulate and $354 \pm 97$ and $131 \pm 31 \mathrm{ng} \mathrm{kW}^{-1}$ $\mathrm{h}^{-1}$ in vapour phase. Since the lighter PAHs were not determined, it was not possible to establish a comparison between their emissions from both fuels. Benzo(a)pyrene (BaP), a carcinogenic and mutagenic PAH, was present in emissions with mean quantities of $610 \pm 29$ and $614 \pm 301 \mathrm{ng}$ $\mathrm{kW}^{-1} \mathrm{~h}^{-1}$ in particulate phase of diesel and B20 respectively. The mean values were considerably lower in the vapour phase $\left(73 \pm 29\right.$ and $\left.24 \pm 12 \mathrm{ng} \mathrm{kW}^{-1} \mathrm{~h}^{-1}\right)$.

Similar conclusions were also obtained by Bünger et al. ${ }^{117}$ regarding the PAH emissions by both diesel and methyl ester of rapeseed oil, running in passenger cars. They also found higher mutagenic potency in exhausts 
from diesel, when compared to that from rapeseed oil ester, and have concluded that this was probably due to the greater amount of PAHs, in the emissions from the fossil fuel. Costa Neto et al. ${ }^{118}$ presented the utilization of used frying oil for the production of biodiesel, and discussed the performance of biodiesel in diesel engines. The emissions derived from engines running on unused vegetable oils were compared to those derived from engines running on conventional diesel. Two nitro-PAHs were also determined, namely 2-nitrofluorene (2-NFLU) and 1-nitropyrene (1-NP). The mean values for their sum, in emissions from diesel and B20 were, respectively, $156 \pm 22$ and $248 \pm 169 \mathrm{ng} \mathrm{kW}^{-1} \mathrm{~h}^{-1}$, with predominance of NFLU. Regarding the carbonyl compounds, the sum of the twelve, found in this work, gave values of 79.3 and $94.5 \mathrm{mg} \mathrm{kW}^{-1} \mathrm{~h}^{-1}$ for diesel and B20. Formaldehyde, followed by acetaldehyde, were the two most abundant in both fuels, with average values of 42.7 and $15.8 \mathrm{mg}$ $\mathrm{kW}^{-1} \mathrm{~h}^{-1}$ in diesel and 50.6 and $16.8 \mathrm{mg} \mathrm{kW}^{-1} \mathrm{~h}^{-1}$ in B20. Results of this study point to an increase in carbonylic compound emissions, when biodiesel is blended with diesel, although different and conflicting results can be found in the literature. ${ }^{110,119}$

Biodiesel blends with diesel are expected to emit less light aromatic compounds than pure diesel, since in the vegetal oil there is virtually no aromatic content. TurrioBaldassari et al. ${ }^{90}$ had observed this in their work, with mean values of 29.9 and $13.9 \mathrm{mg} \mathrm{kW}^{-1} \mathrm{~h}^{-1}$ for diesel and B20, respectively, benzene and toluene comprising more than $60 \%$ of the total. Despite this, it is important to highlight that in other works distinct results were also reported. ${ }^{110,119}$

\section{Conclusions}

The number of articles and patents on biodiesel testifies to the growth of interest in this subject. Especially USA, Japan and European countries have dedicated efforts to reach a good technological level for biodiesel production. Soybean is the most commonly used oil source, but the chosen source changes from place to place according to the availability. Regarding the seeds, good sources should have low production costs, high percentages of oil and high yields per hectare. The increasing use of recycled oil as a biodiesel source is due to its lower cost in relation to raw or refined oils. From the chemical point of view, good oil for biodiesel production must be rich in long chain and low unsaturation level fatty acids.

The transesterification process in an industrial unit can be summarized as following: the oil, after acid correction, is transferred to the principal reactor. In a second reactor, the catalyst $(\mathrm{KOH}$ or $\mathrm{NaOH})$ and the alcohol $(\mathrm{MeOH}$ or EtOH) are homogenized and transferred to the principal reactor. The reaction is completed in $40 \mathrm{~min}$, at a temperature between 30 and $40{ }^{\circ} \mathrm{C}$. The biodiesel (upper layer) is then separated from the raw glycerine (lower layer) by decantation (on batch process) or by centrifugation (on continuous process). The lower layer, besides raw glycerine, contains part of the alcohol that could be recovered and reused in the process. The raw glycerine could be purified and used, for example, in the cosmetic industry.

There has been a continuous development of new catalysts for biodiesel production, especially for heterogeneous processes. Regarding the development of new catalysts for homogeneous processes, there are few articles in the literature. Among the heterogeneous catalysts, it could be observed that enzymes are the most commonly studied in the last few years. However, the performance is still unfavourable compared to the alkaline homogeneous catalysts. The use of different available acid and alkaline catalysts has been reviewed and particular attention has been given to the more recently developed ones.

GC and HPLC are the most commonly employed methods for characterization of biodiesel composition. HPLC is a technique that gives good results but the cost of the analysis is a little higher than GC. Thus, GC is preferred to quantify biodiesel.

Results available till now, regarding comparative studies between emissions from pure fossil diesel and mixtures, in variable proportions, with biodiesel, are still conflicting in several aspects. While some studies report, for biodiesel, overall reductions in almost all regulated substances, others point to comparable values or even increases in emissions. Also, while regulated emissions are by now already reasonably well documented in several works, non-regulated emissions, on the contrary, lack more substantial research. Differences between emissions, produced by fuel burning, depend on factors that are not only related to the type of fuel, but also to engine characteristics and test conditions. The combination of all of these variables may be leading to the different conclusions, among the studies conducted till now, but is also an encouragement for further researches.

\section{Brazilian Perspectives}

Despite the potential in Brazil for oleaginous cultivation, and consequently for biodiesel production, there are challenges for setting up and consolidating a wide program of biodiesel use as fuel. The principal challenges and considerations focused technological, agronomic and infrastructure areas. 


\subsection{Technological perspectives}

(i) Develop new process of transesterification (heterogeneous catalysts, ethylic route, etc.), with the possibility of reduction of by-products and costs with separation and purification of biodiesel; (ii) improve the product stability by use of additives; (iii) optimize the industrial plants to obtain control of the continuous process; (iv) improve the quality standard of biodiesel to avoid motor and environmental damage; $(v)$ investigate new uses for glycerine; ( $v i)$ evaluate and control the quality of vehicle emissions in motors using biodiesel as fuel.

\subsection{Agro-economic perspectives}

(i) Plan and execute an ecologically sustainable agricultural zoning of oleaginous cultivation; (ii) assure supply of raw material with minimal costs to the producer; (iii) establish financial support to amplify the cultivation of oil plants; ( $i v)$ develop research to select new varieties and systems of tilling with low environmental impact; $(v)$ intensify search for genetic improvement of oil plants, with the purpose of increased productivity and yield of oil for biodiesel; (vi) develop technology to use the tart castor bean and tart soy as animal feed.

\subsection{Infrastructure perspectives}

(i) Improve the infrastructure of transport and distribution; (ii) improve the connections of the productive chain.

\subsection{Environmental perspectives}

(i) Reduce the emissions of harmful species (e.g. CO, particulate matter, sulphur compounds and THC); (ii) get a clear diagnosis on the environmental impacts of biofuel uses, along with its advantages and benefits.

\section{Acknowledgments}

The authors wish to thank CNPq, ANEEL, ANP, FAPERJ and FAPESB.

\section{Abbreviation List}

$\Delta \quad$ position of double bond in fatty acids

ANEEL Agência Nacional de Energia Elétrica

ANP Agência Nacional de Petróleo

ASTM American Society for Testing and Materials

B100 pure biodiesel

B20 20\% B100 and $80 \%$ diesel

$\begin{array}{ll}\text { B30 } & 30 \% \text { B100 and } 70 \% \text { diesel } \\ \text { B35 } & 35 \% \text { B100 and } 65 \% \text { diesel } \\ \text { B5 } & 5 \% \text { B100 and } 95 \% \text { diesel } \\ \text { B2 } & 2 \% \text { B100 and } 98 \% \text { diesel } \\ \text { BaP } & \text { benzo(a)pyrene }\end{array}$

BIREME Latin American and Caribbean Center on Health Sciences Information

CNPq Conselho Nacional de Desenvolvimento Científico e Tecnológico

ETS-10 titanosilicate structure-10 zeolite

FAPERJ Fundação de Amparo à Pesquisa do Estado do Rio de Janeiro

FAPESB Fundação de Amparo à Pesquisa do Estado da Bahia

FAPESP Fundação de Amparo à Pesquisa do Estado de São Paulo

FAs fatty acids

FID flame ionization detection

GC gas chromatography

HC hydrocarbons

${ }^{1} \mathrm{HNMR}$ hydrogen nuclear magnetic resonance

HPLC high performance liquid chromatography

IF impact factor

INPADOC International Patent Documentation Center

INPI Instituto Nacional da Propriedade Industrial

MS mass spectrometry

2-NFLU 2-nitrofluorene

$\mathrm{NO}_{\mathrm{x}} \quad$ nitrogen oxides

1-NP 1-nitropyrene

PAHs polycyclic aromatic hydrocarbons

PCT Patent Cooperation Treaty

PM particulate matter

SOF soluble organic fraction

STO sulphated tin oxide

SZA sulphated zirconia-alumina

TBD 1,5,7-triazabicyclo[4,4,0]dec-5-ene

TGA thermo-gravimetric analysis

THC total hydrocarbons

TLC thin layer chromatography

USPTO United States Patent and Trademark Office

$\mathrm{v} / \mathrm{V} \quad$ volume/volume proportion

VOCs volatile organic compounds

WZA tungstated zirconia-alumina

\section{References}

1. Sá Filho, H. L.; Rotenberg, B.; Albuquerque, S. F.; Mendonça, M. C. G.; Medeiros, P. R. S.; Informativo do INT 1979, 12, 29.

2. Ma, F.; Hanna, M. A.; Bioresour. Technol. 1999, 70, 1.

3. Meher, L. C.; Sagar, D. V.; Naik, S. N.; Renew. Sustain. Energy Rev. (in press, available on line at www.sciencedirect.com). 
4. Pioch, D.; Lozano, P.; Rasoanantoandro, M. C.; Graille, J.; Geneste, P.; Guida, A.; Oleagineux 1993, 48, 289.

5. Schwab, A. W.; Dykstra, G. J.; Selke, E.; Sorenson, S. C.; Pryde, E. H.; J. Am. Oil Chem. Soc. 1988, 65, 1781.

6. Goering, C. E.; Fry, B.; J. Am. Oil Chem. Soc. 1984, 61, 1627.

7. Bagby, M. O.; Fuel 1987, 66, 1372.

8. Ali, Y.; Hanna, M. A.; Bioresour. Technol. 1994, 47, 131; Meiring, P.; Hansen, A. C.; Vosloo, A. P.; Lyne, P. W. L.; Trans. ASAE 1983, 26, 59; Kass, M. D.; Thomas, J. F.; Storey, J. M.; Domingo, N.; Wade, J.; Kenereck, G.; Soc. Automot. Eng., [Spec. Publ.] SP 2001, SP-1632, 2001.

9. De Caro, P. S.; Mouloungui, Z.; Vaitilingom, G.; Berge, J. C.; Fuel 2001, 80, 565.

10. Fernando, S.; Hanna, M.; Energy Fuels 2004, 18, 1695.

11. Ziejewski, M.; Kaufman, K.R.; Pratt, G.L.; Seminar II, Northern Regional Research Center, Peoria (Illinois), USA, 19-20 October, 1983.

12. Muniyappa, P. R.; Brammer, S. C.; Noureddini, H.; Bioresour. Technol. 1996, 56, 19.

13. Haas, M. J.; Fuel Process. Technol. 2005, 86, 1087.

14. Demirbas, A.; Energy Convers. Manage. 2003, 44, 2093.

15. Abreu, F. R.; Lima, D. G.; Hamú, E. H.; Wolf, C.; Suarez, P. A. Z.; J. Mol. Catal. A: Chem. 2004, 209, 29.

16. Srivastava, A.; Prasad, R.; Renew. Sustain. Energy Rev. 2000, 4, 111.

17. Fukuda, H.; Kondo, A.; Noda, H.; J. Biosci. Bioeng. 2001, 92, 405.

18. Ugarte, D. G. T.; Ray, D. E.; Biomass Bioenergy 2000, 18, 291.

19. Fröhlich, A.; Rice, B.; Indust. Crops Prod. 2005, 21, 25.

20. Tan, R. R.; Culaba, A. B.; Purvis, M. R. I.; Biomass Bioenergy 2004, 26, 579.

21. Barnwal, B. K.; Sharma, M. P.; Renew. Sustain. Energy Rev. 2005, 9, 363.

22. Encinar, J. M.; Gonzalez, J. F.; Rodr1guez, J. J.; Tejedor, A.; Energy Fuels 2002, 16, 443.

23. Kamini, N. R.; Fujii, T.; Kurosu, T.; Iefuji, H.; Process Biochem. (Oxford, U. K.) 2000, 36, 317.

24. Shah, S.; Sharma, S.; Gupta, M. N.; Energy Fuels 2004, 18 , 154.

25. Pramanik, K.; Renew. Energy 2003, 28, 239.

26. Raheman, H.; Phadatare, A. G.; Biomass Bioenergy 2004, 27 , 393.

27. Goodrum, J. W.; Geller, D. P.; Bioresour. Technol. 2005, 96, 851.

28. Puhan, S.; Vedaraman, N.; Ram, B. V. B.; Sankarnarayanan, G.; Jeychandran, K.; Biomass Bioenergy 2005, 28, 87.

29. Scragg, A. H.; Morrison, J.; Shales, S. W.; Enzyme Microb. Technol. 2003, 33, 884.

30. Altýn, R.; Cetinkaya, S.; Yucesu, H. S.; Energy Convers. Manage. 2001, 42, 529.
31. Ramadhas, A. S.; Jayaraj, S.; Muraleedharan, C.; Renew. Energy 2005, 30, 795 .

32. Ikwuagwu, O. E.; Ononogbu, I. C.; Njoku, O. U.; Indust. Crops Prod. 2000, 12, 57.

33. Usta, N.; Biomass Bioenergy 2005, 28, 77.

34. Knothe, G.; Fuel Process. Technol. 2005, 86, 1059.

35. Holanda, A.; Biodiesel e inclusão social, Brasília: Câmara dos Deputados, Coordenação de Publicações, Série Caderno de Altos Estudos, 2004, vol. 1.

36. Ferrari, R. A.; Oliveira, V. S.; Ardalla Scabio, A.; Quim. Nova 2005, 28, 19.

37. Vicente, G.; Martínez, M.; Aracil, J.; Bioresour. Technol. 2004, 92, 297.

38. Schuchardt, U.; Sercheli, R.; Vargas, R. M.; J. Braz. Chem. Soc. 1998, 9, 199.

39. Fukuda, H.; Kondo, A.; Noda, H.; J. Biosci. Bioeng. 2001, 92 , 405.

40. Bondioli, P.; Top.Catal. 2004, 27, 77.

41. Lang, X.; Dalai, A. K.; Bakhshi, N. N.; Reaney, M. J.; Hertz, P. B.; Bioresour. Technol. 2001, 80, 53.

42. Schuchardt, U.; Vargas, R. M.; Gelbard, G.; J. Mol. Catal. A: Chem. 1995, 99, 65.

43. Abreu, F. R.; Lima, D. G.; Hamú, E. H.; Einloft, S.; Rubim, J. C.; Suarez, P. A. Z.; J. Am. Oil Chem. Soc. 2003, 80, 601.

44. Schuchardt, U.; Vargas, R. M.; Gelbard, G.; J. Mol. Catal. A: Chem. 1996, 109, 37.

45. Gelbard, G.; Vielfaure-Joly, F.; C. R. Acad. Sci. Paris, series IIc, Chimie/Chemistry 2000, 3, 563.

46. Peter, S. K. F.; Ganswindt, R.; Neuner, H. P.; Weidner, E.; Eur. J. Lipid Sci. Technol. 2002, 104, 324.

47. Suppes, G. J.; Bockwinkel, K.; Lucas, S.; Botts, J. B.; Mason, M. H.; Heppert, J. A.; J. Am. Oil Chem. Soc. 2001, 78, 139.

48. Leclercq, E.; Finiels, A.; Moreau, C.; J. Am. Oil Chem. Soc. 2001, 78, 1161.

49. Suppes, G. J.; Dasari, M. A.; Doskocil, E. J.; Mankidy, P. J.; Goff, M. J.; Appl. Catal. A: Gen. 2004, 257, 213.

50. Kim, H-J.; Kang, B-S.; Kim, M-J.; Park, Y. M.; Kim, D-K.; Lee, J-S.; Lee, K-Y.; Catal. Today 2004, 93, 315.

51. Monteiro, R. S.; Cruz, R. S.; Abstracts of the $27^{a}$ Reunião Anual da Sociedade Brasileira de Química and XXVI Congresso Latinoamericano de Química, Salvador, Brazil, 2004.

52. Reis, S. C. M.; Reid, M. G.; Nascimento, R. S. V.; Lachter, E. R.; Abstracts of the $12^{\circ}$ Congresso Brasileiro de Catálise, Angra dos Reis, Brazil, 2003.

53. Furuta, S.; Matsuhashi, H.; Arata, K.; Catal. Commun. 2004, 5,721 .

54. Samukawa, T.; Kaieda, M.; Matsumoto, T.; Ban, K.; Kondo, A.; Shimada, Y.; Noda, H.; Fukuda, H.; J. Biosci. Bioeng. 2000, 90, 180.

55. Kamini, N. R.; Iefuji, H.; Process Biochem. 2001, 37, 405.

56. Watanabe, Y.; Shimada, Y.; Sugihara, A.; Tominaga, Y.; J. Mol. Catal. B: Enzymatic 2002, 17, 151. 
57. Köse, Ö.; Tüter, M.; Aksoy, H. A.; Bioresour. Technol. 2002, $83,125$.

58. Pizarro, A. V. L.; Park, E. Y.; Process Biochem. 2003, 38, 1077.

59. Shieh, C-J.; Liao, H-F.; Lee, C-C.; Bioresour. Technol. 2003, 88, 103.

60. Kaieda, M.; Samukawa, T.; Kondo, A.; Fukuda, H.; J. Biosci. Bioeng. 2001, 91, 12.

61. Iso, M.; Chen, B.; Eguchi, M.; Kudo, T.; Shrestha, S.; J. Mol. Catal. B: Enzymatic 2001, 16, 53.

62. Soumanou, M. M.; Bornscheuer, U. T.; Enzyme Microb. Technol. 2003, 33, 97.

63. Shimada, Y.; Watanabe, Y.; Samukawa, T.; Sugihara, A.; Noda, H.; Fukuda, H.; Tominaga, Y.; J. Am. Oil Chem. Soc. 1999, 76, 789 .

64. Samukawa, T.; Kaieda, M.; Matsumoto, T.; Ban, K.; Kondo, A.; Shimada, Y.; Noda, H.; Fukuda, H.; J. Biosci. Bioeng. 2000, 90, 180.

65. Shantha, N. C.; Napolitano, G. E.; J. Chromatogr. A 1992, 624, 37.

66. Carelli, A. A.; Cert, A.; J. Chromatogr. A 1993, 630, 213.

67. James, A. T.; Martin, A. J. P; Biochem. J. 1952, 50, 679.

68. Choi, M. N.; Chung, B. C.; Anal. Biochem. 2000, 277, 271.

69. Christie, W. W.; Lipids 1998, 33, 343.

70. Czauderna, M.; Kowalczyk, J.; J. Chromatogr. B: Enzymatic 2001, 760, 165 .

71. Li, Z.; Gu, T.; Kelder, B.; Kopchick, J. J.; Chromatographia 2001, 54, 463.

72. Sanches-Silva, A.; Quirós, A. R-B.; López-Hernández, J.; Paseiro-Losada, P.; J. Chromatogr. A 2004, 1032, 7.

73. Dorado, M. P.; Ballesteros, E.; Lopes, F. J.; Mittelbach, M.; Energy Fuels 2004, 18, 77.

74. Alcantra, R.; Amores, J.; Canoira, L.; Fidalgo, E.; Franco, M. J.; Navarro, A.; Biomass Bioenergy 2000, 18, 515.

75. Kusdiana, D.; Saka, S.; Fuel 2001, 80, 693.

76. Chen, J-W.; Wu, W-T.; J. Biosci. Bioeng. 2003, 95, 466.

77. Madras, G.; Kolluru, C.; Kumar, R.; Fuel 2004, 83, 2029.

78. Dmytryshyn, S. L.; Dalai, A. K.;Chaudhari, S. T.; Mishra, H. K.; Reaney, M. J.; Bioresour. Technol. 2004, 92, 55.

79. Gelbard, G.; Brès, O.; Vargas, R. M.; Vielfaure, F.; Schuchardt, U. F.; J. Am. Oil Chem. Soc. 1995, 72, 1239.

80. Gandhi, N. N.; Mukherjee, K. D.; J. Agric. Food Chem. 2000, $48,566$.

81. Stavarache, C.; Vinatoru, M.; Nishimura, R.; Maeda, Y.; Ultrason. Sonochem. 2005, 12, 367.

82. Tomasevic, A. V.; Siler-Marinkovic, S. S.; Fuel Process. Technol. 2003, 81, 1 .

83. Bradshaw, G.B.; Meuly, W.C.; US Pat. 2,360-844, 1944.

84. Trent, W. R.; US pat. 2,383,632, 1945.

85. Smith, M. K.; US pat. 2,486,444, 1949

86. Wimmer, T.; US pat. 5,399,731, 1992.
87. Stern, R.; Hillion, G.; Rouxel, J.J.; US pat. 5,424,466, 1995.

88. Portaria 310, 12/27/2001-ANP and Resolução 42, 11/ 24/ 2004-ANP, http://www.anp.gov.br/petro/legis_biodiesel.asp, accessed in May, 2005.

89. He, B. Q.; Shuai, S. J.; Wang, J. X.; He, H.; Atmos. Environ. 2003, 37, 4965.

90. Turrio-Baldassarri, L.; Battistelli, C. L.; Conti, L.; Crebelli, R.; De Berardis, B.; Iamiceli, A. L.; Gambino, M.; Iannaccone, S.; Sci. Total Environ. 2004, 327, 147.

91. Kleindienst, T. E.; Smith, D. F.; Li, W.; Edney, E. O.; Driscoll, D. J.; Speer, R. E.; Weathers, W. S.; Atmos. Environ. 1999, 33, 3669.

92. Pereira, P. A. de P.; de Andrade, J. B.; Quim. Nova 1998, 21, 744.

93. Pereira, P.A. de P.; Santos, E. T. S.; Ferreira, T. de F; de Andrade, J. B.; Talanta 1999, 49, 245.

94. Martins, E. M.; Correa, S. M.; Arbilla G.; Atmos. Environ. 2003, 37, 23.

95. de Andrade, M. V.; Pinheiro, H. L. C.; Pereira, P. A. de P.; de Andrade, J. B.; Quím. Nova 2002, 25, 1117.

96. Tanner, R. L.; Miguel, A. H.; de Andrade, J. B.; Gaffney, J. S.; Streit, G. E.; Environ. Sci. Technol. 1988, 22, 1026.

97. Miguel, A. H.; de Andrade, J. B.; J. Braz. Chem. Soc. 1990, 1, 124.

98. Pereira, P. A. de P.; Santos, L.M.B.; Sousa, E.T.; de Andrade, J. B.; J. Braz. Chem. Soc. 2004, 15, 646.

99. Bagley, S. T.; Gratz, L. D.; Johnson, J. H.; McDonald, J. F.; Environ. Sci. Technol. 1998, 32, 1183.

100. Wang, W. G.; Lyons, D. W.; Clark, N. N.; Gautan, M.; Norton, P. M.; Environ. Sci. Technol. 2000, 34, 933.

101. Sharp, C.; Howell, S.; Jobe, J.; SAE Tech. Pap. Ser. 2000, No. 2000-01-1967.

102. Durbin, T. D.; Collins, J. F.; Norbeck, J. M.; Smith, R.; Environ. Sci. Technol. 2000, 34, 349.

103. Durbin, T. D.; Norbeck, J. M.; Environ. Sci. Technol. 2002, $36,1686$.

104. Clark, N. N.; Lyons, D. W.; Trans. ASAE 1999, 42, 1211.

105. Schumacher, L. G.; Clark, N. N.; Lyons, D. W.; Marshall, W.; Trans. ASAE 2001, 44, 1461.

106. Gomez, M. E. G.; Howard-Hildige, R.; Leahy, J. J.; O’Reilly,T.; Supple, B.; Malone, M. Environ. Monit. Asses. 2000, 65, 13.

107. Dorado, M. P.; Ballesteros, E.; Arnal, J. M.; Gómez, J.; López, F. J.; Fuel 2003, 82, 1311.

108. Kalam, M. A.; Masjuki, H. H.; Biomass Bioenergy 2002, 23, 471.

109. Rantanen, L.; Mikkonen, S.; Nylund, L.; Kociba, P.; Lappi, M.; Nylund, N. O.; SAE Tech. Pap. Ser. 1993, No 932686.

110. Sharp, C.; Howell, S.; SAE Tech. Pap. Ser. 2000, No 2000-011968.

111. Zou, L.; Atkinson, S.; Environ. Technol. 2003, 24, 1253.

112. Schumacher, L.; Borgelt, S. C.; SAE Tech. Pap. Ser. 1996, $N^{o}$ 962233. 
113. Chang, D. Y. Z.; VanGerpen, J. H.; Lee, I.; Johnson, L. A.; Hammond, E. G.; Marley, S. J.; J. Amer. Oil Chem. Soc. 1996, 73, 1549.

114. Peterson, C. L.; Reece, D. L.; Thompson, J. C.; Beck, S. M.; Chase, C.; Biomass Bioenergy 1996, 10, 331.

115. Peterson, C.; Reece, D.; Transactions of the ASAE 1996, 39, 805.

116. Puhan, S.; Vedaraman, N.; Ram, B. V. B.; Sankarnarayanan, G.; Jeychandran, K.; Biomass Bioenergy 2005, 28, 87.
117. Bünger, J.; Krahl, J.; Franke, H.; Munack, A.; Hallier, E.; Mutat. Research 1998, 415, 13.

118. Costa Neto, P. R.; Luciano F. S. Rossi, L. F. S.; Zagonel, G. F.; Ramos, L. P.; Quim. Nova 2000, 23, 531.

119. Krahl, J.; Munack, A.; Bahadir, M.; Schumacher, L.; Elser, N.; SAE Tech. Pap. Ser. 1996, No 962096.

Received: April 5, 2005 Published on the web: October 6, 2005 